\title{
Nepheline syenites to syenites and granitic rocks of the Itatiaia Alkaline Massif, Southeastern Brazil: new geological insights into a migratory ring Complex
}

\author{
Pedro Augusto da Silva Rosa ${ }^{1 *}$, Excelso Ruberti ${ }^{1}$
}

\begin{abstract}
The Itatiaia Alkaline Massif comprises some of the largest meso-cenozoic alkaline igneous occurrences in Brazil, covering over 215 km² between the states of Minas Gerais and Rio de Janeiro. It appears as an elongated, 30-km long and 4.5-11.5-km wide SE-NW-trending body emplaced along accommodation zones of the Continental Rift of Southern Brazil, intruding metapelites, orthogneiss and granites of the Brasilia and Ribeira fold belts. New data and geological mapping suggest that the massif evolved from a migratory magmatic center manifested as ring structures and successive moon-shaped intrusions from SE to NW in three sectors of distinct lithological and geomorphological characteristics: Southeastern, Central and Northwestern. The lithological variants in the three sectors present themselves as discrete intrusive bodies, comprising feldspathoid-bearing and quartz-bearing syenites, porphyritic to breccioid trachytes, granite, monzonite, gabbro and trachybasalt, which can be grouped into 21 units. These rocks occur in five petrographical sets: plagioclase-free nepheline syenites, plagioclase-bearing nepheline syenite and pulaskites, nordmarkite-granite series, anti-rapakivi associations and basic rocks. Sin- to tardi-plutonic dykes of nephelinites, phonolites, trachytes and rhyolites are also present.
\end{abstract}

KEYWORDS: Alkaline rocks; Nepheline syenite; Quartz syenite; Geological mapping; Itatiaia.

\section{INTRODUCTION}

Alkaline rocks are defined by the presence of feldspathoids, sodic pyroxene and/or sodic amphibole, thus rocks that can be either undersaturated or oversaturated with silica. A silica-saturated liquid may evolve toward a foid-syenite or a granite eutectic, but it cannot evolve to both terms in the same process (e.g. Hamilton \& MacKenzie 1965, Sørensen 1974, Foland et al. 1993, Nekvasil et al. 2004, Gupta et al. 2010). Nevertheless, the association of nepheline syenite and quartz syenite is common in many alkaline provinces and in different tectonic contexts. Typically, they form ring complexes that can be categorized into three types of occurrences:

- Massifs composed of silica-undersaturated rocks in their central portions and quartz-bearing rocks in their border zones, their spatial distribution being either gradual or marked by different intrusions, e.g., Abu Khruq, Egypt (Mogahed 2016), Ilímaussaq and Kangerlussuaq,
Greenland (Marks \& Markl 2001, Riishuus et al. 2008) and Messum, Namibia (Harris et al. 1999);

- Massifs with quartz-bearing rocks only in their central portions, shielded from contact with country rocks (at least at surface level) by silica-undersaturated rocks, e.g., Itatiaia, in Brazil (Penalva 1967, Ribeiro Filho 1967, Brotzu et al. 1997), Wadi Dib, in Egypt (Frisch \& Abdel-Rahman 1999), Hekanzi, in China (Yang et al. 2012) and Pilanesberg, in South Africa (Cawthorn 2015);

- Massifs composed exclusively, or predominantly, of quartz-bearing rocks associated with other silica-undersaturated massifs in the same magmatic province, e.g., Cerro Pedreira and Morro Distante, Alto Paraguay Province, Paraguay (Comin-Chiaramonti et al. 2015), Paresis, Damaraland Province, Namibia (Mingram et al. 2000) and Sabongari, Cameroon Line, Cameroon (Njonfang et al. 2013).

${ }^{1}$ Instituto de Geociências, Universidade de São Paulo, São Paulo (SP), Brazil.E-mails: pedrorosa@usp.br, pasr86@hotmail.com 
The Itatiaia Alkaline Massif (IAM) is one of the few meso-cenozoic alkaline occurrences in Brazil with a variation from $\mathrm{SiO}_{2}$-undersaturated rocks on their borders to silica-oversaturated rocks in their core regions. The massif is notable for its progressively inward increase in $\mathrm{SiO}_{2}$ content, and also for the presence of an alkaline granite body and rhyolitic dykes in its central portions.

The study presented here was based on petrographic information, detailed fieldwork and remote sensing, and aimed at a reevaluation of the IAM geology. The massif shows to be of much higher geological complexity and lithologic variation than described in previous studies. The objective here is to present a new geology reading of the region, with a description of its main structures and lithological diversity and the relations among them. A detailed geological map is also presented, with emphasis on faciology and petrography. Twenty-one different magmatic units (in addition to internal facies variations) of feldspathoid-bearing and quartz-bearing syenite, trachyte, granite, monzonite, gabbro and dykes of nephelinite, phonolite, trachyte and rhyolite are defined.

\section{Area of study}

Covering an area of approximately $215 \mathrm{~km}^{2}$, the IAM is one of the largest meso-cenozoic alkaline occurrences in Brazil, located between the homonymous city in the state of Rio de Janeiro and Itamonte, in Minas Gerais $\left(22^{\circ} 18^{\prime} / 22^{\circ} 28^{\prime} S\right.$; $\left.44^{\circ} 34^{\prime} / 44^{\circ} 49^{\prime} \mathrm{W}\right)$. About three-quarters of the massif belong to the Itatiaia National Park (PNI), the first Brazilian one, established in 1937. An important landmark in southeastern Brazil, the massif shows a rugged topography (approximately $40 \%$ of its area is above the altitude of $2,000 \mathrm{~m}$ ). Thirteen of the 35 highest peaks in the country, among which the famous Agulhas Negras (2,792 m), the fifth highest one, are within its limits. Its lowest altitude point $(560 \mathrm{~m})$ is located near the park entrance. Most of the massif is covered by Atlantic rain forest, showing an astonishing diversity of natural resources. Montane rain forest occurs above the altitude of $1,500 \mathrm{~m}$, with significant presence of araucaria trees. Between the altitudes of 1,800 and 1,900 m, the rupestrian grassland of montane savanna begins, with trees becoming progressively shorter and scarcer until completely disappearing. In the far northwest of the massif, pastures and crops occur.

\section{Previous works}

The Itatiaia Massif was one of the first regions of scientific interest in Brazil. For its important historical, biological, ecological, geomorphological, touristic, mountaineering and other aspects, it has been studied for almost two centuries. The first scientific work in the region was carried out in 1872 Glaziou, who collected a large number of new plant species, in an expedition of which Isabel, Imperial Princess of Brazil took part (Brade 1956). Ule was the first one to mention the local fauna in 1894 (Pinto 1950). Despite its broad extension, lithologic diversity and historical importance, the IAM has been subject of only a few geological studies.

In the first geological study of the IAM, Silva (1876) suggested that the Itatiaia Mountain had been formed by volcanic processes in an igneous terrain. Later, Silva (1882) presented petrographic information on a granite body and some vague aspects of other rock types. Silva, also known as Massena, was an important personality in the region and the first one to climb the Agulhas Negras Peak in 1856.

The occurrence of alkaline rocks in Brazil was first reported by Lasaulx (1885) in the Itatiaia Massif, who described a fine-grained nepheline syenite with orthoclase, plagioclase, augite with hornblende rims, idiomorphic nepheline, abundant titanite and biotite and a porphyritic nepheline syenite with intergrown of orthoclase and nepheline, and idiomorphic nepheline, augite, hornblende and titanite as well.

Lamego (1936) described varieties of nepheline and quartz-bearing lithotypes and their approximate localization, photomicrography and geochemistry, including the Passa Quatro and Morro Redondo massifs (the nearest alkaline occurrences) as a unique foyaite body. The local magmatism was associated to the formation of Tertiary basins, and from geomorphologic observations, an Upper Cretaceous age was assigned to the massif.

Penalva (1967) and Ribeiro Filho (1967) carried out the most detailed geological studies on the massif, describing a great variety of lithotypes and drawing its first geological map (Ribeiro Filho \& Penalva 1965). Four lithological associations were mapped: nepheline syenite and syenite, quartz syenite, magmatic breccia and granite. They also discussed the massif genesis and evolution and its relations to Passa Quatro and Morro Redondo.

Brotzu et al. (1997) presented important mineral chemical, geochemical and isotopic data and also discussed petrological and petrogenetic aspects of the massif. Modifications to the previous map were proposed, with individualization of some internal variations and structural features.

Enrich et al. (2005) and Brotzu et al. (2005) revised all the previous data in a discussion of petrogenetic models, contrasting the massif with the Passa Quatro and São Sebastiāo stocks.

Finally, Melluso et al. (2017) presented new mineral chemical data on the main lithologies of the IAM, especially on accessory phases of peralkaline syenites and granites and their genetic relationships with evolved lithotypes. 


\section{METHODOLOGY}

In this study, 233 outcrops were visited and 256 rock samples collected. Their location, landmarks, buildings and sites used as references in the text, are presented as supplementary data (see Suppl. Tab. A1). Many areas of the massif are inaccessible due to topography and/or exposure constraints.

Lithological units were individualized based on fieldwork information and petrographical (texture and accessory mineralogy of 120 thin sections), geochemical, structural and geomorphological features. All units are interpreted as corresponding to distinct pulses and/or correlated magmatic events. They are cartographically continuous at the working scale of 1:75,000 (present here at the scale of $\sim 1: 143,000$ ) and were drawn based on Google Earth (Google Earth 2015) and Landsat 8 LC82180752013189LGN00 (Image courtesy of the U.S. Geological Survey) satellite imagery and ASTER GDEM ASTGTM2_S23W045 (ASTER GDEM is a product of METI and NASA). Some units show significant internal variation, but there is currently not enough information on how to individualize them. Due to the larger number of outcrops described and better exposure and geomorphology, mapping is more detailed in the central part of the massif. Geochemical, isotopic, mineral chemical and geochronological data (Rosa 2017) were also considered in the individualization of units. Country rock units were compiled from Trouw et al. (2003) and Heilbron et al. (2016). Geological contacts were categorized as: known, when a sudden geological change was directly noticed in field (direct contacts were not observed) and/or satellite imagery observation with good fieldwork control; inferred, when change was unclear or fieldwork control was insufficient; and supposed, when based only on some indication, with insufficient or missing fieldwork control. Internal facies were also individualized, based on a sector, unit and facies hierarchy.

Phaneritic rocks were identified according to their modal QAPF - Q: quartz; A: alkali feldspar; P: plagioclase; F: feldspathoid - plots and aphanitic rocks were identified in the TAS diagram, with fields after Le Maitre (2002). Except for fine-grained types, modal analyses of thin sections were performed for representative samples of each unit. Pulaskite, nordmarkite and alaskite are synonyms for nepheline-bearing alkali feldspar syenite, quartz-bearing alkali feldspar syenite and leucocratic alkali feldspar granite, respectively (Le Maitre 2002).

The geological map in Figure 1 was compiled from: Leite et al. (2004), Valeriano et al. (2011), Alves et al. (2015), Cioffi et al. (2015) and Janasi et al. (2015) for regional basement; Riccomini (1989), Meisling \& Cob (2001) and Zalán \& Oliveira (2005) for Cenozoic tectonic; and Almeida (1983, 1991), Schobbenhaus et al. (1984), Motoki (1986),
Bellieni et al. (1990), Ferrari (2001), Chiessi (2004), Trouw et al. (2007), Brotzu et al. (2007), Heilbron et al. (2007), Azzone et al. (2009), Enrich et al. (2009), Guarino et al. (2011) and Rosa (2012) for alkaline provinces and massifs.

\section{GEOLOGICAL CONTEXT}

The IAM is emplaced in a region of complex geological history in the limits of Brasília and Ribeira orogenic belts, where a continental rift system was developed by reactivation of old shear zones.

\section{Precambrian basement}

The southeastern portion of the massif intrudes garnet-sillimanite-muscovite-schists of the Embú Group (Paraíba do Sul Terrain) and banded (garnet)-biotite-gneiss and amphibolites of the Raposo Group (Occidental Terrain), Ribera Belt (Heilbron et al. 2004, 2016, Mendes et al. 2006, Trouw et al. 2013). Following the ENE-WSW trend of the Ribeira Belt, Ediacaran granites of the Andrelândia Domain are also present, locally represented by foliated porphyritic biotite granites of the Serra Selada and Maromba suits (Mendes et al. 2006). The Rio Jaguari Shear Zone delimits the Riberia and Brasília fold belts (Campos Neto et al. 2011). The northwestern portion of the massif intrudes a sequence of paragneiss-metatexite (with amphibolite, muscovite schists and quartzite subordinated layers), hornblende-biotite migmatitic orthogneiss and synorogenic leucogranites of the neoproterozoic Socorro-Guaxupé Nappe of the Brasilia fold belt (Heilbron et al. 2004, Campos Neto et al. 2011, Trouw et al. 2013).

\section{Meso-Cenozoic tectonics and magmatism}

An extensional tectonic event in the Upper Jurassic started the opening of the South Atlantic Ocean. In the Brazilian Platform, this event, named Wealdenian Reactivation (Almeida 1967, 1969), was characterized by reactivation of faults, arc uplift, subsidence of the Paraná Basin and development of coastal basins and intense tholeiitic magmatism in the Paraná-Etendeka Magmatic Province (134-131 Ma.; e.g. Thiede \& Vasconcelos 2010, Janasi et al. 2011). Such processes allowed for the manifestation of repeated alkaline magmatic activity through arcs, flexures and failure zones both surrounding the Paraná Basin and on adjacent coasts to Santos Basin (Almeida 1971, 1983, Algarte 1972, Almeida et al. 1996, Riccomini et al. 2005). More than a hundred large to small bodies, swarms of dykes and lava flows, characterize this magmatism, of a large compositional variation from ultrabasic to acid and ultrapotassic to sodic rocks (Gomes \& Comin-Chiaramonti 2005). 
An Upper Cretaceus epirogenetic mega plateau is recorded as the Japi Planation Surface, in apatite fission track data, and in the thickness of sedimentary rock layers of the Santos and Campos basins (Almeida 1976, 1983, Zalán \& Oliveira 2005, Cogné et al. 2012, Rezende et al. 2013, Engelmann de Oliveira et al. 2016). The uplifted areas became isostatically unstable and their gravitational collapse resulted in several tafrogenic basins from the State of Paraná to northern Rio de Janeiro (Continental Rift of Southeastern Brazil, CRSB; Riccomini 1989, Riccomini et al. 2004). The intense plot of shear zones of the Ribeira fold belt was reactivated as normal faults parallel to coastlines during the Paleogene and as transcurrent faults in the Neogene (Almeida 1976, 1983, Mello et al. 1985, Riccomini 1989, Riccomini et al. 2004, Zalán \& Oliveira 2005). An association among the magmatic activity along the Serra do Mar range and several alkaline intrusions and dikes from 82 to $52 \mathrm{Ma}$ and the development of the CRSB seems clear.

\section{The Cabo Frio Magmatic Lineament}

The Cabo Frio Magmatic Lineament (CFLM; Sadowski \& Dias Neto 1981, Almeida 1991, Thomaz Filho \& Rodrigues 1999, Riccomini et al. 2005) is a curved, $60-\mathrm{km}$ wide and $1,150-\mathrm{km}$ long belt that extends from Jaboticabal to the coastal banks of Almirante Saldanha. About 30 alkaline intrusive bodies as large as massifs, stocks, plugs, lava flows and dike swarms are arranged along the lineament. These rock bodies are essentially composed by nepheline syenites, syenites, phonolites and trachytes with potassic affinity. Except for the Poços de Caldas Massif $\left(-800 \mathrm{~km}^{2}\right)$, Bom Repouso and Caxambú stocks (both $\sim 1 \mathrm{~km}^{2}$ ) and some dikes, these occurrences took place inside or at the edge of CRSB (Fig. 1).

The CFML's age apparently ranges eastward, from 84 to $52 \mathrm{Ma}$. Many studies aimed at an explanation of this progression, linking it to transform faults (e.g. Marsh 1973), mantle plumes (e.g. Thompson et al. 1998, Thomaz Filho \& Rodrigues 1999) and subcrustal faulting (e.g. Almeida

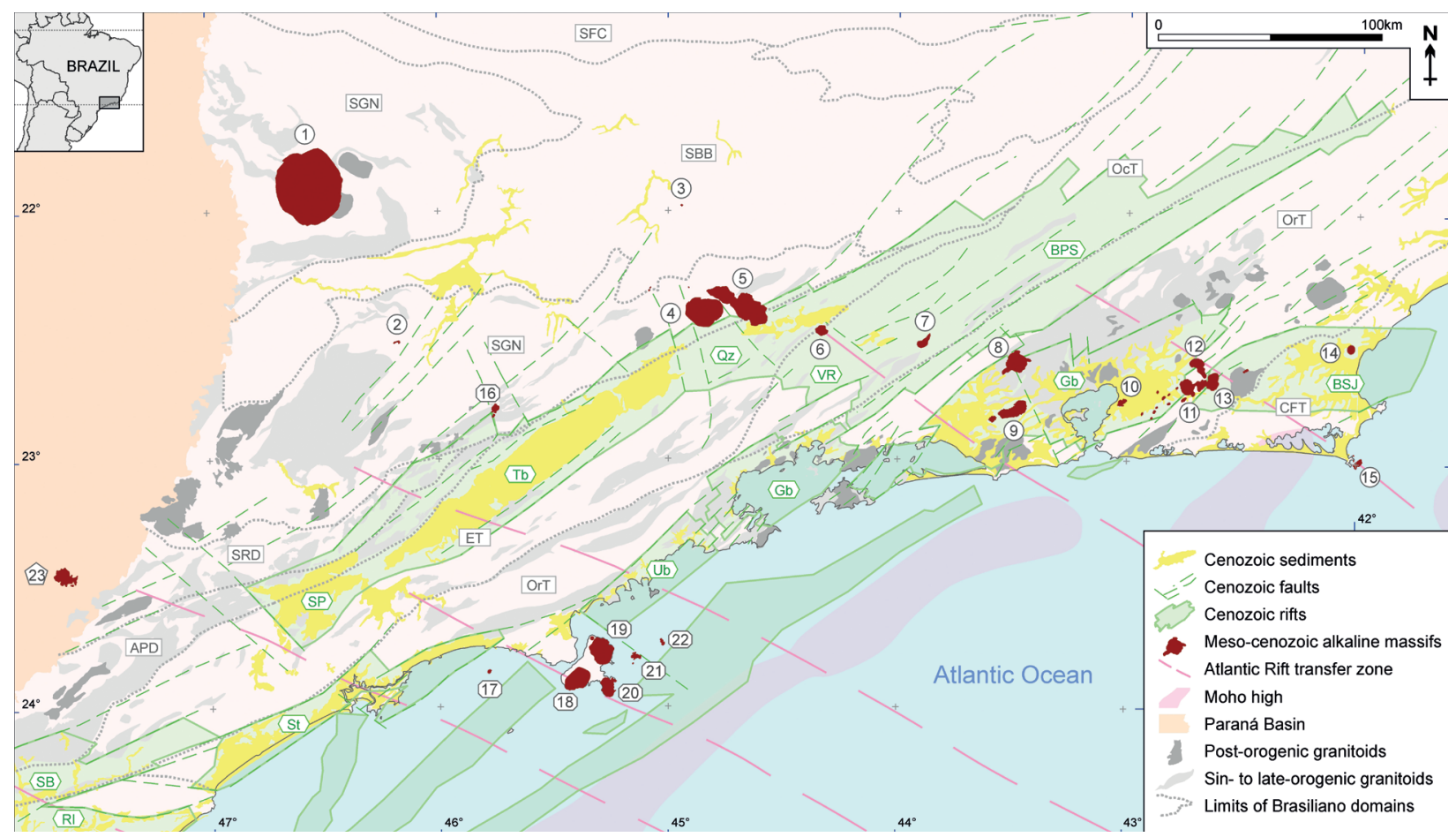

Figure 1. Distribution of the Meso-Cenozoic alkaline occurrences of Serra do Mar Province (modified after Almeida 1983, 1991; Schobbenhaus et al. 1984), with the CRSB (Riccomini 1989), the main Brasiliano tectonic domains and sin- to post-orogenic granitoids. Alkaline occurrences: Poços de Caldas (1), Bom Repouso (2), Caxambú (3), Passa Quatro (4), Itatiaia (5), Morro Redondo (6), Serra dos Tomazes (7), Tinguá (8), Mendanha-Mapicuru (9), Itaúna (10), Tanguá (11), Soarinho (12), Rio Bonito (13), Morro de São João (14), Cabo Frio (15), Ponte Nova (16), Monte de Trigo (17), São Sebastião (18), Serraria (19), Mirante (20), Búzios (21), Vitória (22) and another occurrence near SMP Ipanema (23). Rifts: Paraíba do Sul, São Paulo (SP), Taubaté (Tb), Queluz (Qz), Resende-Volta Redonda (RVR), Baixo Paraíba do Sul (BPS); Coastal: Sete Barras (SB), Ribeira de Iguape (RI), Santos (St), Ubatuba (Ub), Guanabara (Gb), Barra do São João (BSJ). Brasiliano domains: Socorro-Guaxupé Nappe (SGN), South Brasília Belt (SBB), São Roque Domain (SRD), Apiaí Domain (APD), Embú Terrain (ET), Ocidental Terrain (OcT), Oriental Terrain (OrT), Cabo Frio Terrain (CFT). Compiled from: cartographic base (Leite et al. 2004), Cenozoic tectonics (Riccomini 1989, Zalán \& Oliveira 2005), and therein references (See text for other references). 
1991, Ferrari 2001, Riccomini et al. 2005, Zalán \& Oliveira 2005). However, the progression from WNW to ESE is not linear, and more detailed geochronological studies are necessary. Their ages are, for instance: Jaboticabal, $54 \mathrm{Ma}$ (K-Ar method; Gomes \& Valarelli 1970); Poços de Caldas, 84-76 Ma (Ar-Ar; Shea 1992, Vlach et al. 2003); Bom Repouso, 79-76 Ma (Ar-Ar; Rosa et al. 2014); Itatiaia, 71-67 Ma (U-Pb; Rosa 2017); dikes in the Resende and Volta Redonda basins, 82-59 Ma (K-Ar, Ar-Ar; Guedes et al. 2005); ankaramitic lavas in Volta Redonda and Itaboraí basins, $43 \mathrm{Ma}$ (K-Ar; Riccomini \& Rodrigues-Francisco 1992); Mendanha, 73-71 Ma (K-Ar; Thompson et al. 1998); Soarinho 65-62 Ma (K-Ar; Thompson et al. 1998); and Cabo Frio, 55-52 Ma (K-Ar, Ar-Ar; Thompson et al. 1998, Bennio et al. 2003).

It is remarkable that most of the CFML alkaline bodies tend to be in contact or intruding Neoproterozoic sin-, lateor post-orogenic K-high calc-alkaline granites and syenites of the Ribeira and Brasília fold belts, especially in the Socorro Nappe, Apiaí Domain and Oriental Terrain (e.g. Valeriano et al. 2011, Tupinambá et al. 2012, Carvalho et al. 2014, Janasi et al. 2015, Alves et al. 2016). The post-orogenic granitoids also have mantellic isotopic signatures (e.g., Janasi et al. 2009, Valeriano et al. 2011, Carvalho et al. 2014) and are oriented to NE-SW (the same trend of Brasiliano faults) with Cenozoic alkaline massifs.

\section{GEOLOGICAL SETTING}

The IAM is an elongated body, $30-\mathrm{km}$ long and 4.5 to $11.5-\mathrm{km}$ wide SE-NW-trending feature. Most of its units are moon-shaped and align successively to the Northwest (Fig. 2). Its structures and lithotype associations suggest three sectors whose characteristics could represent distinct origin and/or evolution stages.

The Southeastern Sector (SE-S) consists of miaskitic to agpaitic nepheline syenite bodies cut by dykes of aphiric, porphyritic (some of them with pseudoleucite) and breccioid phonolites and nephelinites. The most silica-undersaturated units are on the edge, in contact with basement rocks, being locally peraluminous with modal hercynite and corundum.

The Central Sector (C-S) corresponds to a ring-like structure with a 9.5 to $11.5 \mathrm{~km}$ diameter (Fig. 3), which partially intrudes the SE-S. It shows an external C-shape ridge with well-defined topographic expressions in its northern and eastern parts, lower in the south and almost absent in the west, consisting of miaskitic to agpaitic nepheline syenites with a 60 to $200 \mathrm{~m}$ wide belt of sin-plutonic swarm of trachyte dykes that sustains its external parts. Inner units are composed of different pulaskites, nordmarkites and quartz alkali feldspar syenites, whose silica saturation tends to increase inward. A small intrusive body of alaskite occurs next to the center of the ring, where dykes of trachyte and rhyolite occur. A 'neck' is formed in the transition area to the Northwestern Sector, consisted of anti-rapakivi glomeroporphyritic quartz syenite and porphyritic to breccioid aphanitic trachyte.

The Northwest Sector (NW-S) also shows some moonshaped structures in nepheline syenites and nordmarkites. Locally, cumulatic melagabbro and biotite monzonite occur. Porphyritic to breccioid trachyte and trachybasalt are present in the central parts of the area.

The remarkable structural setting of the massif is evidenced by its drainage system (Fig. 3), the lineaments and faults that shape the relief (Figs. $4 \mathrm{~A}$ and $4 \mathrm{~B}$ ), and the great number of conjugate shear joints in slabs and walls (Fig. 4B). Three preferential direction of lineaments are evident: NW-SE, ENE-WSW and W-E. The first one is clearly observed in the Southeast and Central sectors and coincides with the elongation of the massif. Its main manifestation is the Vale dos Lírios Lineament (VLL). The second is ubiquitous and concordant with the tectonic setting of the basement and CRSB. The third group of lineaments is also ubiquitous, but less expressive and more visible in the Central Sector, and even denser in some belts. Secondary radial lineaments are also present in the external ridge of this sector.

The VLL is longitudinal to the massif, with some magmatic manifestations (microalaskite and aegirine-augite nordmarkite units, the Picu's Rock and the Pedra Furada Hill). It appears as a straight valley in the Central Sector, with some expressiveness in the rest of the massif and outside. However, its kinematics is yet to be clarified; it separates two different geomorphological domains: a plateau with the highest elevations to the north and a scarp and ring features of lesser visible structural pattern to the south. Apparently, the lineament does not mark any lithological change.

Talus deposits occur across the massif and are expressive over the Southeastern and Central sectors borders. Alluvia-formed bogs are present in the high valleys of the Central Sector.

\section{Southeastern Sector}

\section{Nepheline syenite I}

This unit occurs in the southeastern border of the massif, partially covered by talus deposits. Outcropping as rocky hills, small massifs or decametric boulders covered by the dense Atlantic Forest, it probably represents the oldest emplaced and most silica-undersaturated rocks of the massif, with more than $30 \%$ of modal nepheline. This unit shows the strong textural and mineralogical variation that characterizes internal and border facies. 


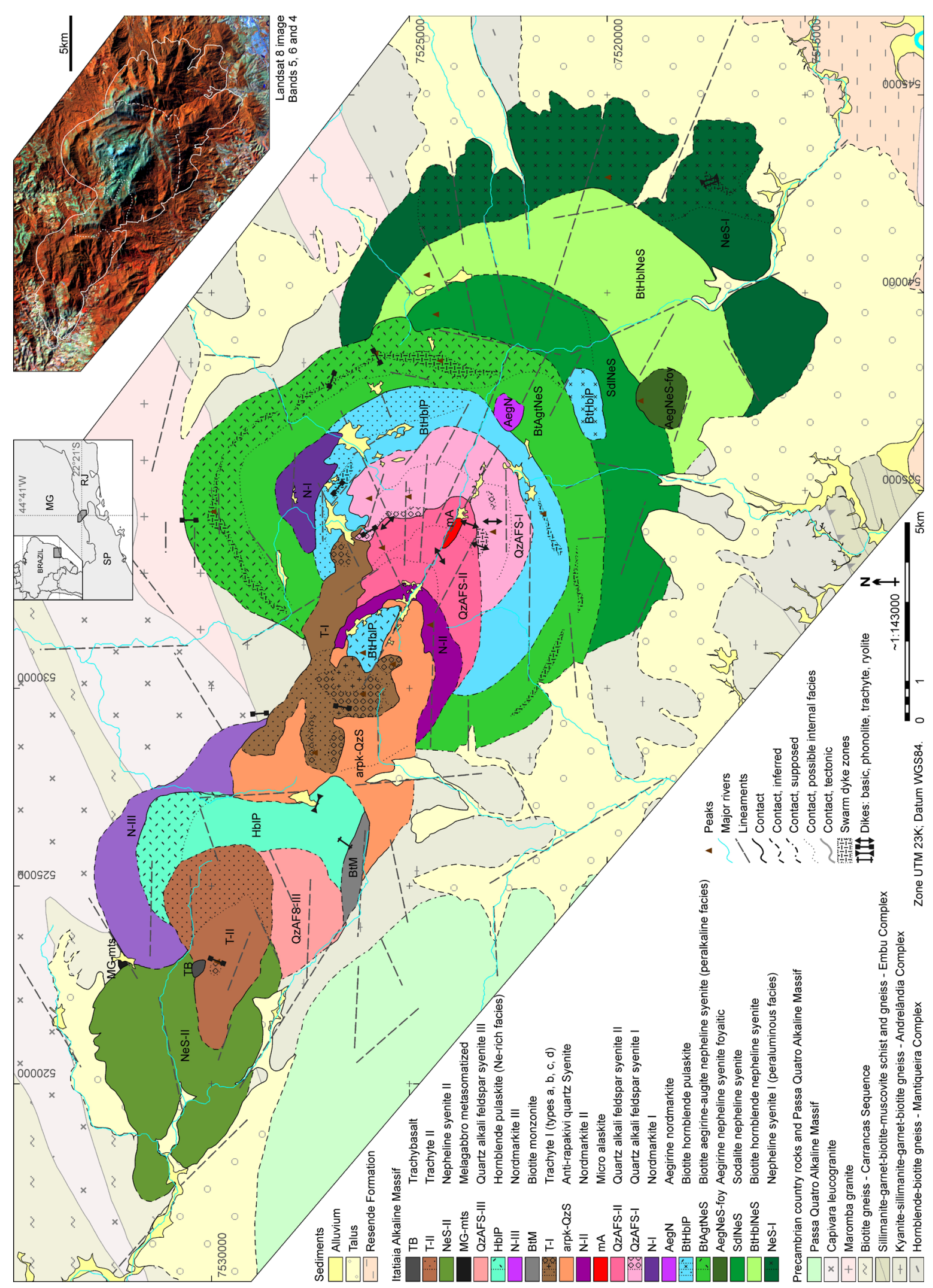

Figure 2. Geological map of the Itatiaia Alkaline Massif. Insert: Landsat 8 image bands 5, 6 and 4 (Image courtesy of the U.S. Geological Survey) for the same delimitated area. Zone UTM 23K; Datum WGS84. 
The predominant internal facies possibly represents the original magma. The best outcrops are found along the road from the park entrance to the museum area. The typical rock is a massive, coarse to medium-grained, inequigranular to equigranular gray to dark gray nepheline syenite (IC -4-8\%). Titanomagnetite, titanite and apatite are early phases. Nepheline is idiomorphic to subidiomorphic, whereas perthitic alkali feldspar is subidiomorphic to interstitial. Xenomorphic to subidiomorphic aegirine-augite is the main mafic mineral, normally zoned with aegirine rims (Fig. 5A). Hiortdahlite is subidiomorphic, sometimes intergrown with titanite and pyroxene. Sodalite, analcime, biotite, carbonate, \pm amphibole, \pm cancrinite and occasional astrophyllite and pyrochlore are late to post magmatic phases. Locally, an association of amphibole biotite replaces clinopyroxene.

The border facies is well observed along the road to Vista Linda Inn and on the Três Picos Hill. The rocks show saccharoidal to oriented, fine to medium-grained texture and gray to dark gray color domains with whitish portions and mafic enclaves. They consist of aluminous assemblages of significant plagioclase, biotite and muscovite, and also hercynite, corundum and rutile (Fig. 5B). An increasing amount of these minerals is followed by a decrease or absence of pyroxene, amphibole, titanite and magnetite. Plagioclase, hercynite and corundum usually appear in association. Centimetric angular mafic microgranular enclaves seldom occur (Figs. 6A and 6B).

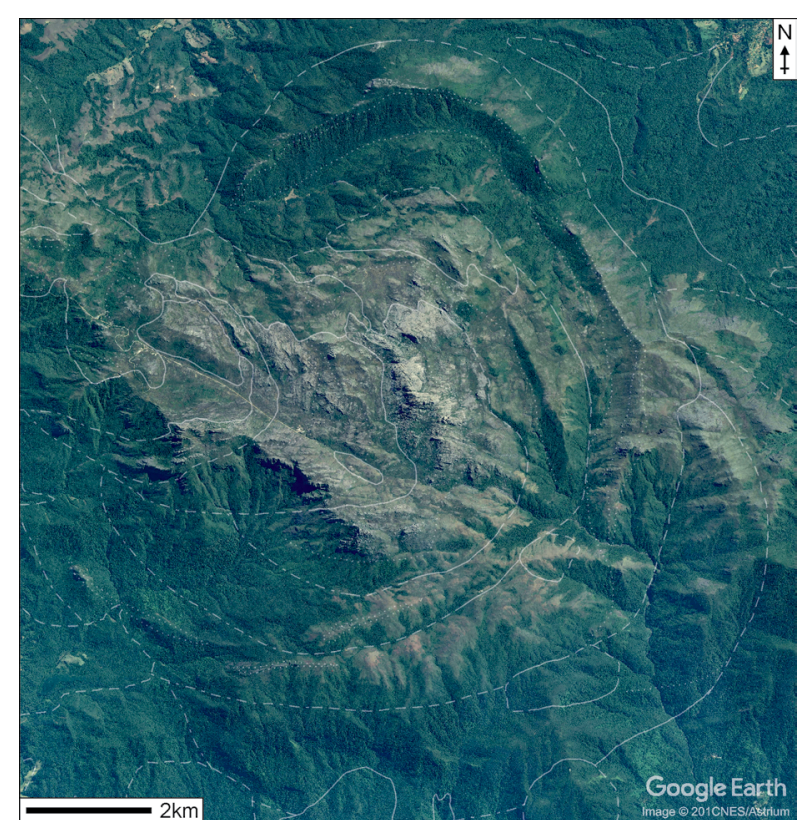

Figure 3. Geomorphological features of the C-S ring, Itatiaia Alkaline Massif; the Vale dos Lírios Lineament with WNW direction in the center. Whitish lines represent contacts in Figure 2. Google Earth (2015).
A swarm of phonolite dykes spreads for over $1.5 \mathrm{~km}$ along the road to Vista Linda Inn. The dykes vary from aphyric with an agpaitic tendency to porphyritic with phenocrysts of alkali feldspar and/or pseudo-leucite (Fig. 6C), but are also breccioid with fragments of syenitic, melanite-bearing mafic, and mylonitic gneissic rocks (Fig. 6D). Aphyric nephelinite also occurs.

\section{Biotite hornblende nepheline syenite}

This unit, that outcrops as a crescent-moon shaped body, is easily recognized on the road from the museum to Véu da Noiva Waterfall and on the trail to Três Picos Hill. It is less silica-undersaturated (5-15 vol\% nepheline) and more mafic (IC 8 to $20 \%$ ) than NeS-I. The rocks are medium to coarsegrained, with an inequigranular, slightly oriented texture and a light-gray color, sometimes with rosy smudges due to the presence of nepheline. Their texture is dominated by tabular to lathlike perthitic alkali feldspar. Carlsbad twinning is common. Interstitial nepheline and aggregates of mafic minerals (Fig. 5C) such as magnesio-hastingsite (up to 8 vol\%) associated with biotite (up to 6 vol\%), titanomagnetite (with titanite rims), xenomorphic titanite (up to 5 vol\%, up to $5 \mathrm{~mm}$ in size, rarely $>10 \mathrm{~mm}$ ), apatite and \pm zircon are also present. Plagioclase $\left(\mathrm{An}_{25-32}\right)$ appears as tabular to rounded xenomorphic crystals, usually with oscillatory zoning and/ or overgrown alkali feldspar and xenomorphic inclusions of sodalite, nepheline and bluish-green amphibole (Fig. 5D). Diopside occurs in almost all samples, in association with amphibole. Weakly zoned magnesio-hastingsite almost completely replaces diopside on the rims, leaving irregular relicts associated with thin veins of titanite in the amphibole cleavage. Subidiomorphic to interstitial biotite is as abundant as amphibole in some places, usually with inclusions of apatite, titanomagnetite, titanite and zircon. Locally, it replaces magnesio-hastingsite. Titanite, biotite and titanomagnetite are usually idiomorphic, while sodalite fills cracks or is included in alkali feldspar. Cancrinite locally replaces nepheline in the final to post magmatic stage.

\section{Sodalite nepheline syenite}

This unit is largely exposed on the trail from the Maromba's Station to the Água Branca Shelter and in talus boulders to the west of the region. The rocks are gray to locally rosy in color and medium to coarse inequigranular in texture. They are similar to those of NeS-I and are characterized by the predominance of slightly oriented tabular mesoperthitic alkali feldspar, usually with Carlsbad twinning and interstitial nepheline (7-15\% vol\%) and sodalite (2-5 vol\%). Subidiomorphic to xenomorphic zoned diopside to aegirine-augite is always associated with biotite (which locally replaces it), titanomagnetite and \pm titanite (IC 5-12\%). 
Sodic amphibole also occurs replacing aegirine-augite. Biotite, titanite and låvenite are the main accessories, while idiomorphic pyrochlore, apatite, \pm fluorite and \pm zircon are less common ones. Carbonate is an interstitial late- to post-magmatic phase that locally replaces biotite.

\section{Aegirine nepheline syenite foyaitic}

This unit only occurs on the Água Branca Shelter Hill, intruding the boundaries of $\mathrm{BtHblNeS}$ and $\mathrm{SdlNeS}$. Its rocks are characterized by a medium-grained foyaitic texture and a high nepheline content ( -30 vol\%), abundant låvenite and the presence of sodic amphibole. Idiomorphic to subidiomorphic nepheline and interstitial sodalite (both up to $1 \mathrm{~mm}$ long) occur among oriented tabular to lathlike mesoperthitic alkali feldspar crystals, which may present Carlsbad and, more rarely, microcline twinning. Interstitial to slightly poikilitic aegirine (Fig. 5E) locally replaced by biotite, låvenite or \pm arfvedsonite, idiomorphic to subidiomorphic låvenite and interstitial arfvedsonite are the main accessories. Minor accessories are titanomagnetite, interstitial ilmenite
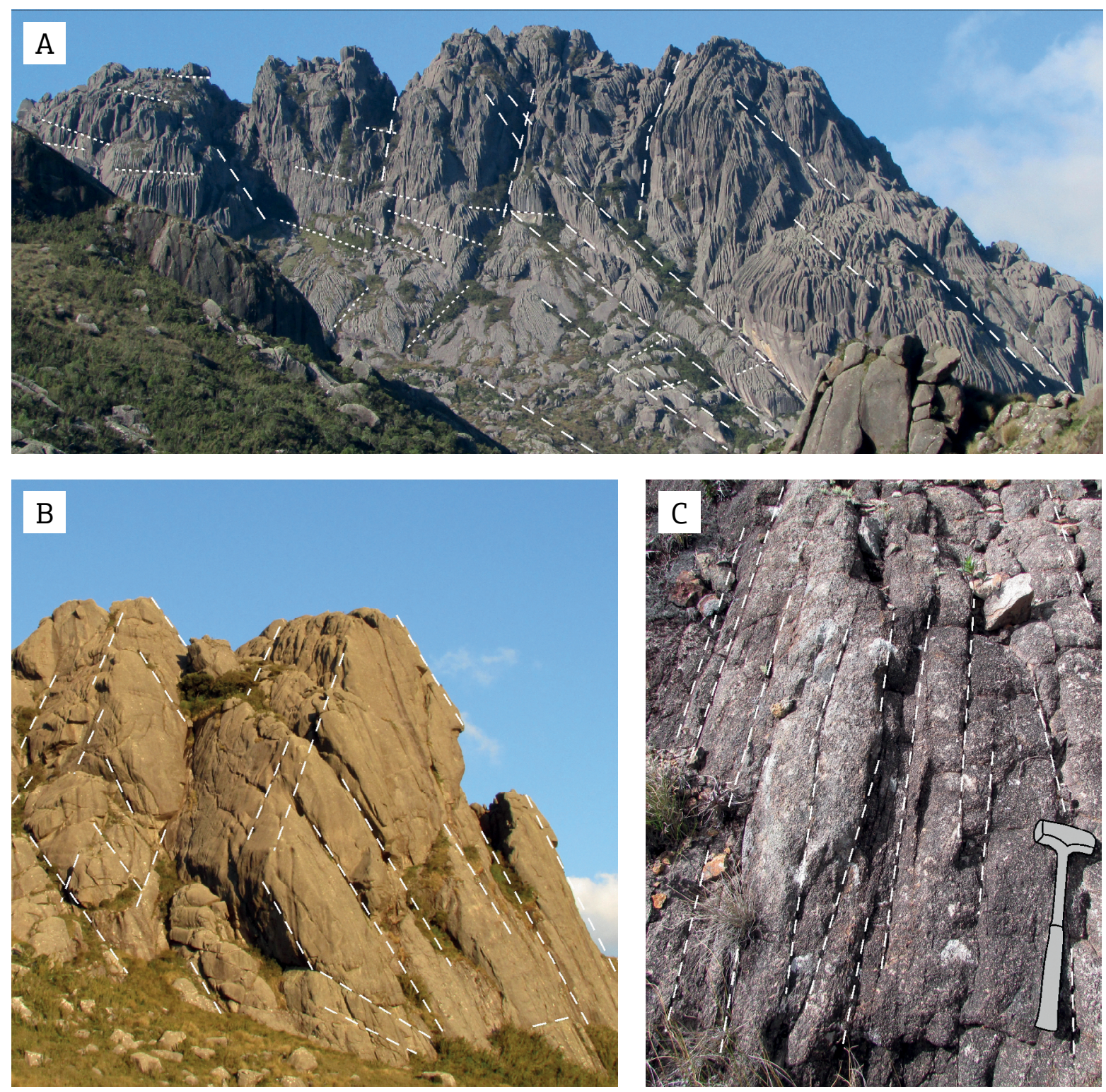

Figure 4. Field aspects of the Itatiaia Alkaline Massif. (A) Fracture plans on the Agulhas Negras Peak, very thin vertical lines corresponding to fluted erosion, which appears as black needles, hence the toponym. (B) Fracture plans on the Pedra do Altar. (C) Conjugate shear joints on the Vale dos Lírios Lineament overlying the $\mathrm{mA}$ unit. Dashed lines highlight structural planes. 
(replaced with aenigmatite), fluorite, apatite, zircon and idiomorphic titanite.

\section{Central Sector}

\section{Biotite aegirine-augite nepheline syenite}

This unit forms the external C-shaped ring of the C-S and shows a transition from miaskitic to agpaitic tendency, which occurs in the highest levels. Along the ridge's crest, trachyte dyke swarms occur, in sin-plutonic intrusive contact (Fig. 7A).
The predominant facies is medium to coarse-grained, with a slightly oriented to massive inequigranular structure and gray to light-gray color (IC 12-20\%). Locally, it can be fine to medium-grained and/or strongly oriented. Caramel titanite crystals $(1-3 \mathrm{~mm}$, up to $10 \mathrm{~mm}$ ) stand out. Perthitic, tabular alkali feldspar with consertal texture and Carlsbad twinning is the main phase, followed by nepheline and sodalite, which occur as subidiomorphic to interstitial crystals. Aegirine-augite to aegirine is the most abundant mafic phase, showing subidiomorphic to interstitial,
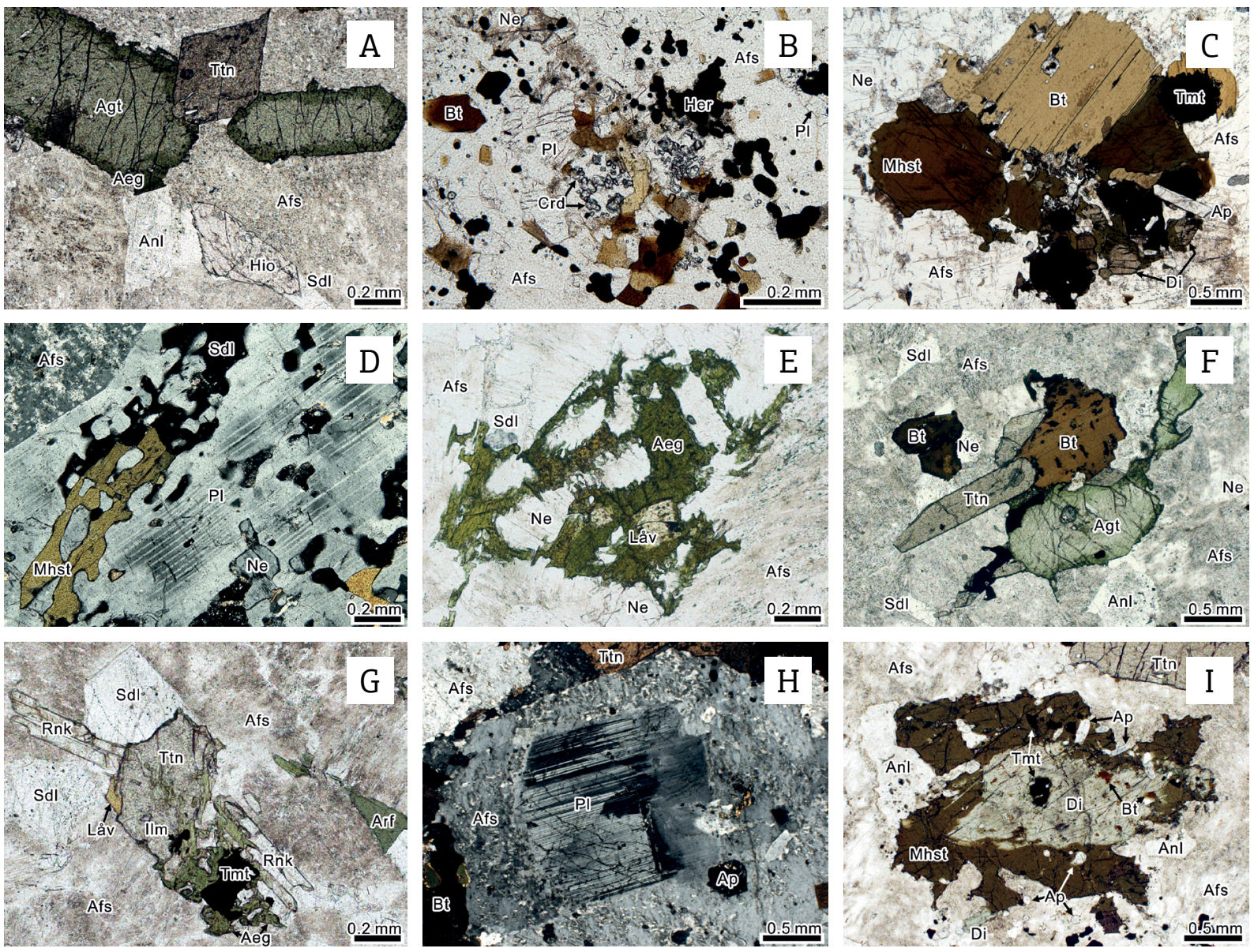

Figure 5. Representative microtextures of rock varieties in the Itatiaia Alkaline Massif. (A) NeS-I, MAIO60. Titanite and aegirine-augite with aegirine border and interstitial hiortdahlite, sodalite and analcime. (B) NeS-I peraluminous facies, MAI030. Aggregate of plagioclase, biotite, hercynite and corundum; note also alkali feldspar and nepheline. (C) BtHblNeS, MAI033. Typical mafic aggregate of magnesio-hastingsite with diopside relicts, biotite, titanomagnetite and apatite; notice the consertal contacts of alkali feldspar and nepheline. (D) BtHblNeS, MAI040. Plagioclase with xenomorphic inclusions of sodalite, nepheline and blueish amphibole. (E) AegNeS-foy, MAI215. Poiquilitic aegirine replaced by låvenite and enclosing nepheline and alkali feldspar; note also nepheline, alkali feldspar and sodalite. (F) BtAgtNeS, MAI206I.Typical mafic aggregate of idiomorphic aegirine-augite and titanite and xenomorphic biotite; notice also alkali feldspar, nepheline, analcime and sodalite. (G) BtAgtNeS peralkaline facies, MAI199. Replacement textures of aegirine with arfvedsonite and titanite by låvenite; notice also xenomorphic titanomagnetite (intergrown with ilmenite), prismatic rinkite, subidiomorphic sodalite and tabular alkali feldspar. (H) BtHblP, MAI092I. Idiomorphic plagioclase overgrown by alkali feldspar (anti-rapakivi); notice the consertal contact of alkali feldspar with biotite and apatite inclusions. (I) BtHblP, MAI114. Typical rreplacement texture of diopside with magnesio-hastingsite, in consertal contact with alkali feldspar and analcime; notice xenomorphic inclusions of titanomagnetite and abundant apatite. See Table 1 for abbreviations. 
occasionally idiomorphic forms (Fig. 5F). Accessory are titanite (with ilmenite relicts), subidiomorphic biotite, titanomagnetite, apatite and \pm zircon.

In Serra Negra Hill and to the east of the Maromba's Hill, a transition from miaskitic to agpaitic paragenesis occurs, with replacement of titanite by làvenite and aegirine by arfvedsonite, and abundant presence of sodalite, rinkite, \pm rosenbuschite and small amounts of biotite (Fig. 5G).

Dikes of dark gray aphyric, fine-grained and strongly orientated trachyte are present (Fig. 7A), with the same paragenesis as the main facies, but with amphibole as an important late magmatic phase.

\section{Biotite hornblende pulaskite}

This unit forms a second C-ring shaped structure, but with remarkable topographic expression only in the eastern part of the massif. Its rocks outcrop around Aiuruoca River Bog, on the crest of Urubu's Hill near Massena Shelter and in other two disconnected annex: in the southeast, apparently intruding SdINeS outside the external ring, and in the northwest, supporting Massena's Hill. In the Massena Shelter region, 2 to $10 \mathrm{~cm}$ wide phonolite dikes outcrop (Fig. 7B). To the east of Ovos da Galinha Boulders, a swarm of up to 1 meter wide and 20 meters long trachyte dikes can be observed in slabs (Fig. 7C). Both groups of occurrences show sin-plutonic intrusive contacts.

The studied rocks are similar to the predominant facies of BtAgtNeS, but are characterized by a lower feldspathoid content (up to 5 vol\%) and a slight porphyritic tendency, with some discrepant tabular feldspar crystals and disequilibrium textures. Locally, crystals show strong magmatic orientation. A border facies with a more prominent medium to fine-grained porphyritic texture occurs in the northern (on Aiuruoca Waterfall) to eastern portion.

Apatite, titanomagnetite, ilmenite, diopside and zircon form the early magmatic assemblage. Perthitic alkali feldspar is subidiomorphic to xenomorphic, with crystals larger than $5 \mathrm{~mm}$ being tabular with Carlsbad twinning.
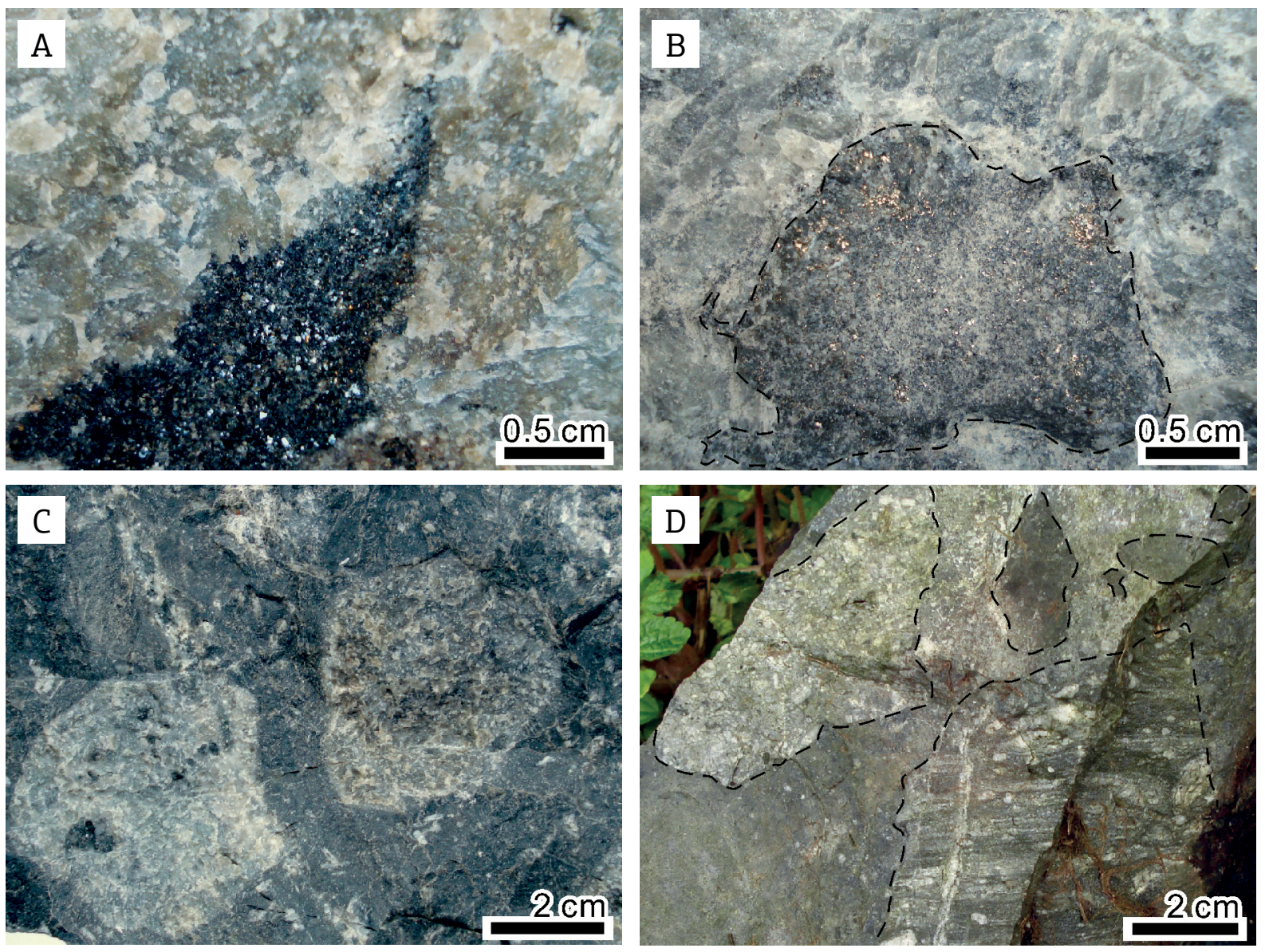

Figure 6. Structural and textural macroscopic aspects of rocks from NeS-I unit in the Itatiaia Alkaline Massif. (A) MAI042. Mafic biotite-rich microgranular enclave. (B) MAI043. Mafic pyrite-rich microgranular enclave. (C) MAI046F. Porphyritic phonolite with pseudoleucite phenocrysts. (D) MAI046G. Breccioid phonolite with syenitic (left), mafic (upper right) and mylonite (lower right) fragments. Dashed lines highlight contacts. 
Amoeboid to idiomorphic cores of plagioclase $\left(\mathrm{An}_{40-50}\right.$; Fig. $5 \mathrm{H}$ ) are usually seen. Magnesio-hastingsite is subidiomorphic to xenomorphic and largely replaces diopside (Fig. 5I). Apatite and titanomagnetite inclusions are common. Subidiomorphic titanite replaces titanomagnetite and ilmenite. Nepheline, sodalite, biotite (locally mantling amphibole) and fluorite are late phases. Analcime represents a late- to post-magmatic phase. Locally, an association of small, scattered subidiomorphic crystals of diopside, zirconolite and pyrite occurs, and their crystallization relations are yet unclear.

The rocks from the southeastern annex are slightly different from the unit's main facies in texture, with local polygonal contact, common Carlsbad twinning and a less perthitic intergrowth of alkali feldspar, scarce amphibole and the presence of pyrite and \pm chevkinite. The rocks from the northwest annex are similar to this unit in texture, but significantly different in mineralogy. They show post magmatic re-equilibration, with microfaults and potassic alteration zones. Pyroxene and/or amphibole are almost totally replaced with biotite, which in turn is replaced with chlorite and carbonate. Neither feldspathoid nor quartz were observed in both appendices.

The trachytes dykes are porphyritic, with an aphanitic matrix and gray color. Well-oriented acicular feldspar and amphibole, idiomorphic magnetite and some unidentified minerals compose the matrix $(<0.2 \mathrm{~mm}$ crystal size). Tabular alkali feldspar $(2-10 \mathrm{~mm})$ and biotite occur as phenocrysts. Phonolites are aphyric, with saccharoidal texture and light gray in color. Texture is granular, with xenomorphic alkali feldspar, nepheline, sodalite, amphibole, magnetite, biotite and zircon (up to $0.4 \mathrm{~mm}$ crystal size).

\section{Aegirine nordmarkite}

This unit outcrops as metric boulders at the Rui Braga trail between the two external rings of the Central Sector and locally interrupting the VLL. It has almost the same relative position of N-I and N-II, intruding BtAgtNeS at the
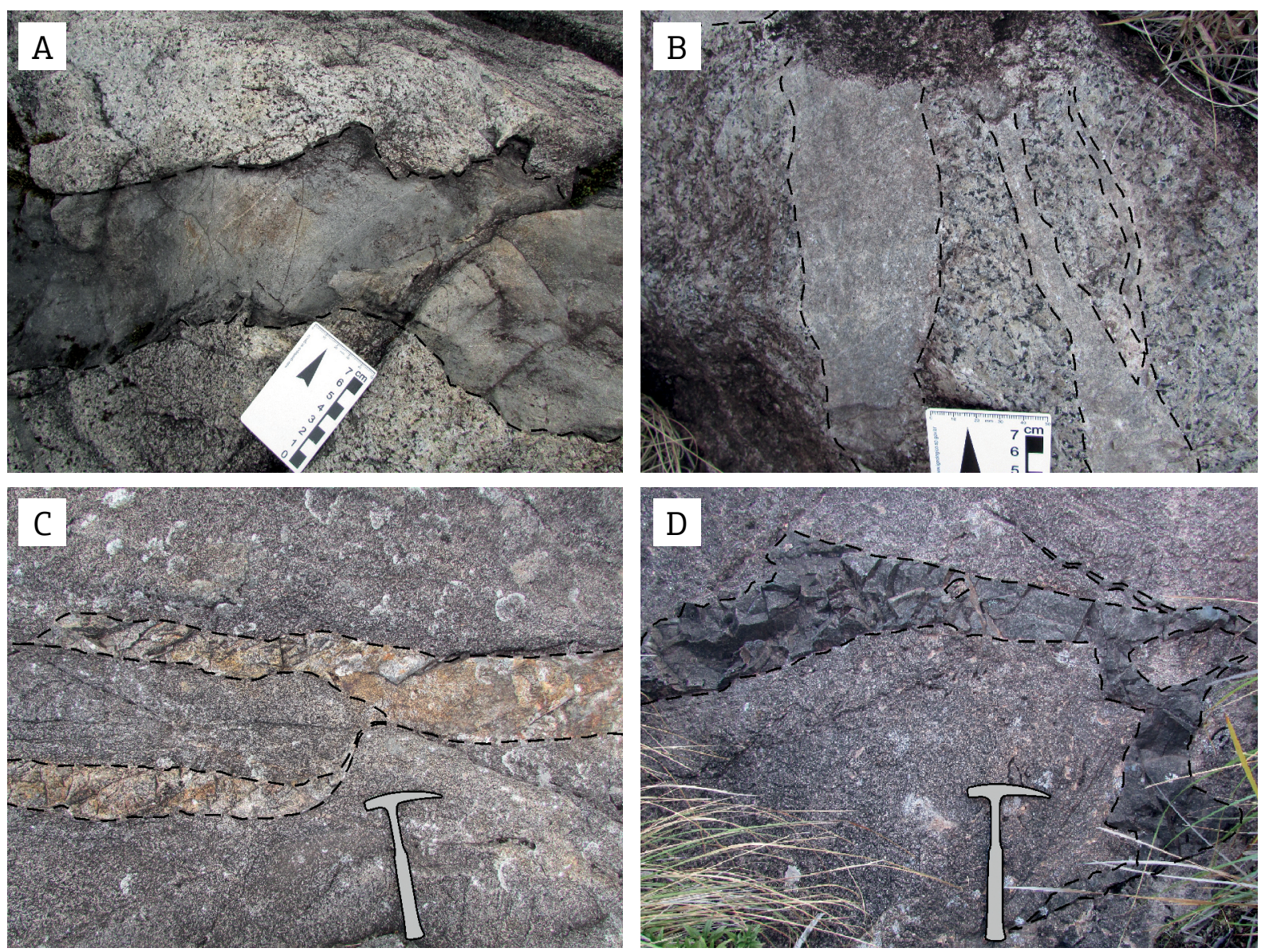

Figure 7. Representative field aspects of Itatiaia Alkaline Massif dikes. (A) Spot close to Maromba's Hill summit. Trachyte showing sinuous sin-plutonic intrusive contacts in the crest of external C-shape ridge. (B) MAI092II. Agpaitic phonolite. (C) MAI100, dike swarm in a slab. Trachyte with sin-plutonic displacement. (D) MAI111. Rhyolite with tardi-plutonic angular contacts. Dashed line highlights contacts. 
borders with BtHblP. The rocks are medium-grained, massive, with inequigranular texture and leaden to light gray in color, with polygonal ochre smudges. Mafic minerals form aggregates (IC 9-11\%). Their texture is dominated by tabular mesoperthitic alkali feldspar with Carlsbad twinning, interstitial aegirine-augite to aegirine and quartz (3-4 vol\%; Fig. 8A). There are associated subidiomorphic titanomagnetite intergrown with ilmenite, zircon, chevkinite, \pm apatite. Pyroxene is moderately homogeneous, however showing instability texture, with sectored exsolutions associated to fluorite. Ankerite, fluorite, REE-fluorcarbonates and ilmenite replace titanite.

\section{Nordmarkite I}

These rocks correspond to the first silica-oversaturated unit, outcropping as a moon-shaped body among the silica-undersaturated units. They can be found to the north and northeast of the Ovos da Galinha Boulders. The rocks are massive, inequigranular, medium- to coarse-grained, leaden-gray in color, with cream-whitish smudges. Texture is
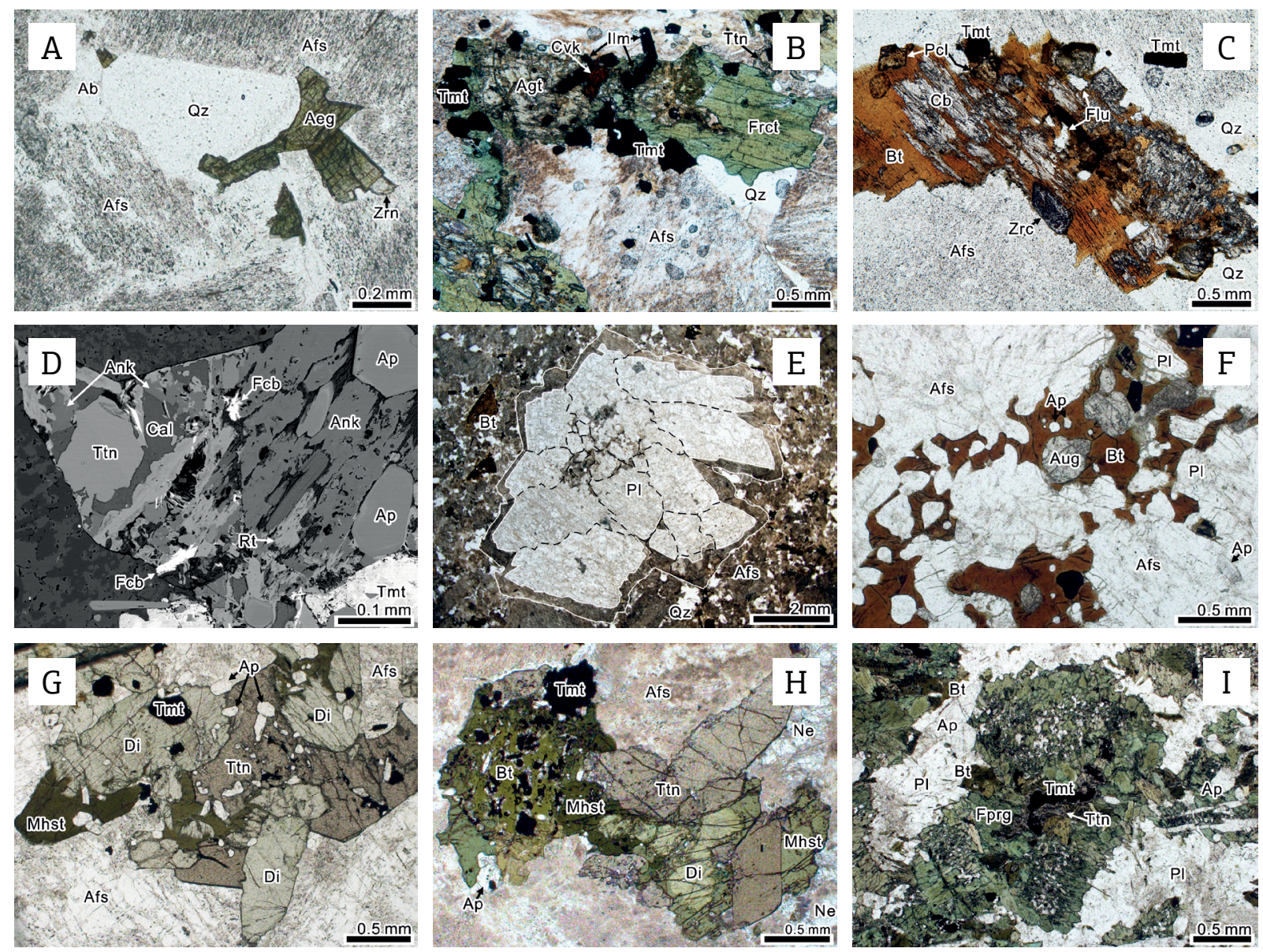

Figure 8. Representative microtextures of rock varieties in the Itatiaia Alkaline Massif. (A) AegN, MAI090. Interstitial quartz and aegirine and albite border in alkali feldspar; notice zircon crystal. (B) QzAFS-I, MAI079. Typical mafic aggregates of ferro-richterite with aegirine-augite relicts and inclusions of titanomagnetite, ilmenite and chevkinite; notice titanite replacement titanomagnetite and interstitial quartz. (C) mA, MAIO70B. Replacement texture in biotite by carbonates and fluorcarbonates; note the inclusions of pyrochlore, fluorite, zircon and titanomagnetite. (D) N-II, MAI136 (BSE image). Association of titanite partially replaced by calcite, ankerite, rutile and REE-fluorcarbonate; notice inclusions of titanomagnetite and apatite. (E) arpk-QzS, MAI108II. Plagioclase aggregate (dashed black lines) overgrown by alkali feldspar (white line); notice the fine groundmass composed by alkali feldspar and quartz. (F) BtM, MAI182C. Poiquilitc biotite enclosing augite, plagioclase, titanomagnetite and apatite. (G) HblP, MAI190. Typical mafic aggregate of diopside partially replaced by magnesio-hastingsite, titanite, titanomagnetite and abundant apatite; note the sharp contact with alkali feldspar. (H) NeS-II, MAI166I. Typical mafic aggregate of diopside, magnesio-hastingsite and biotite in replacement relation between them and titanite, titanomagnetite and apatite; notice nepheline and alkali feldspar. ( I) MG-mts, MAI178. Pseudomorph of pyroxene composed by ferro-pargasite aggregate, biotite, titanomagnetite with titanite corona and alkali feldspar; note apatite inclusions and plagioclase intercumulus. See Table 1 for abbreviations. 
dominated by consertal subidiomorphic alkali feldspar, seldom showing Carlsbad twinning. Mafic minerals aggregates (IC 9-11\%) are present. Quartz (< 4 vol.\%) is interstitial, commonly showing a mirmequitic texture. Mafic aggregates are composed by xenomorphic richterite, occasionally with augite to aegirine relicts (amphibole is absent in one sample), idiomorphic titanomagnetite (commonly with corona of titanite), titanite, \pm ilmenite, \pm zircon (up to $0.5 \mathrm{~mm}$ ) and \pm apatite. Biotite is xenomorphic, locally intergrown with alkali feldspar. Xenomorphic plagioclase $\left(\mathrm{An}_{22}{ }_{25}\right)$ crystals with reabsorption texture and cracked alteration are rare and probably antecrysts.

\section{Quartz alkali feldspar syenite I}

This unit of greatest topographic expression forms the Agulhas Negras Peak and Asa de Hermes, Pedra do Sino, Pedra Assentada and the Prateleiras Hills. It consists of a moon-shaped structure that outcrops as rocky massifs, big slabs and decametric boulders. Fluted and pitted-like erosion structures are typical (Fig. 4A). Millimetric to centimetric miarolitic cavities are common, normally with quartz druses (Fig. 9A).

Its rocks are inequigranular medium- to coarse-grained and light rosy brown in color, with whitish smudges (IC 9-11\%). Tabular microperthitic alkali feldspar predominates, reaching up to $10 \mathrm{~mm}$, mainly with interstitial growth of other minerals. Seldom subidiomorphic, faceted quartz (5-8 vol\%) appears mainly in contact with amphibole. Ferro-richterite is the main mafic mineral, with relics of aegirine-augite in some samples (Fig. 8B). There are also associated prismatic ilmenite, subidiomorphic magnetite, titanite, zircon, chevkinite and apatite, as important accessories. Biotite is uncommon and replaces amphibole. Centimetric, rounded and fine-grained felsic enclaves that highlight on the surface are common in the western border of Agulhas Negras Peak, with more abundant interstitial amphibole and magnetite.

Dikes of aphanitic, aphyric, dark gray rhyolite up to $40 \mathrm{~cm}$ wide with flow-banding texture and angular sharp
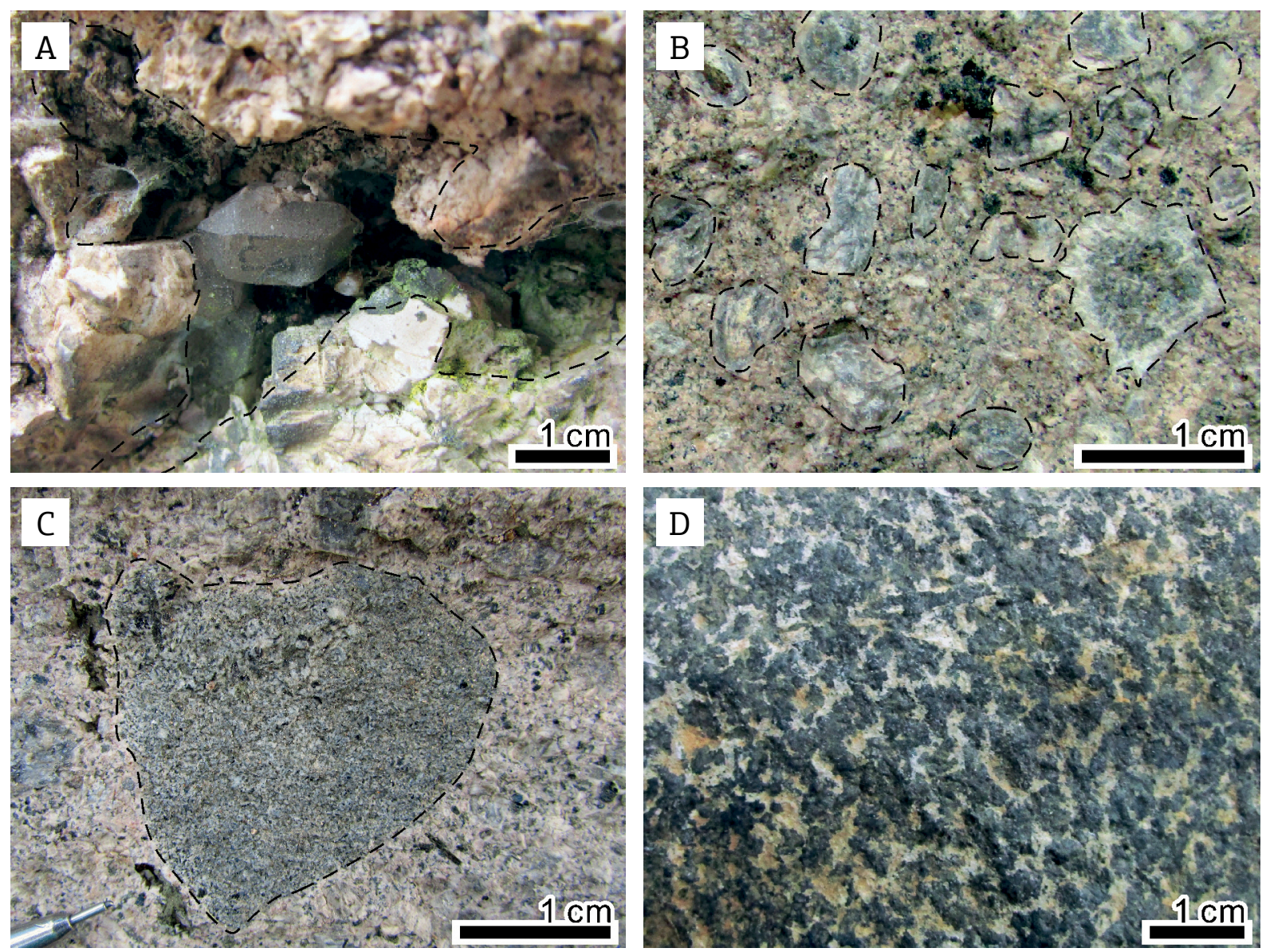

Figure 9. Macroscopic aspects of rock-types in the Itatiaia Alkaline Massif. (A) QzAFS-I, MAI128. Miarolitic cavity with quartz crystals; (B) arpk-QzS, MAI122B. Porphyritic texture with fine-grained groundmass and plagioclase antecrysts; notice remarkable anti-rapakive texture to the right; (C) arpk-QzS, MAI152. Rounded mafic microgranular enclave; (D) MG-mts, MAI178. Cumulatic texture. Dashed lines highlight contacts. 
contacts occur throughout this unit. Occasionally, they are sinuous with sin-plutonic displacement. Some porphyritic dykes with alkali feldspar phenocrysts (up to $5 \mathrm{~mm}$ size) and similar matrix also occur.

\section{Quartz alkali feldspar syenite II}

This unit outcrops near Rebouças Shelter as large rock slabs forming small hills (e.g., the Pedra do Altar Hill), following a moon-shaped sequence and representing the resumption of the northwestward migration of the magmatic center. It comprises three successive facies of little textural and mineralogical differences among them, but brownish to light gray in color with a characteristic medium-grained massif oriented structure and granular texture. These rocks differ from QzAFS-I ones for their higher quartz content (12-18 vol\%), lower IC (7-10\%) and absence of clinopyroxene.

Tabular to xenomorphic mesoperthitic alkali feldspar is the predominant mineral. These rocks also show interstitial to granophyric quartz, zoned amphibole (brown core to pale green to greenish dark blue rim), biotite (locally replacing amphibole) and chevkinite. Apatite, zircon, titanomagnetite and ilmenite, the early magmatic phases, are the main accessories. The central variant facies shows a slightly higher quartz content (graphic texture) and subidiomorphic to interstitial fluorite and allanite. These rocks have been more subject to weathering, with partial replacement of minerals with carbonate. Their internal, mafic facies are slightly oriented.

Rhyolite dikes similar to those of QzAFS-I occur throughout the area (Fig. 7D).

\section{Microalaskite}

These rocks outcrop as an elongated low hill that rises above the VLL in QzAFS-II. They show a massive equigranular medium-grained structure and light creamy gray color (IC - 5\%).

Early mineral phases are apatite, zircon and titanomagnetite. Perthitic to mesoperthitic subidiomorphic tabular alkali feldspar predominates, with a consertal texture and often albitic borders. Quartz (26 vol\%) is commonly intergrown with alkali feldspar, occasionally with granophyric or micrographic texture. Interstitial fluorite, zircon, \pm pyrochlore, \pm monazite and \pm xenotime are associated to subidiomorphic to xenomorphic titanomagnetite. Interstitial biotite apparently replaces amphibole and/or pyroxene, but with no relicts of such minerals and is associated with late- to post-magmatic carbonates, REE-fluorcarbonates and phosphates (Fig. 8C). Prismatic quartz, ankerite and \pm albite fill miarolitic cavities.

\section{Nordmarkite II}

This unit occurs as a C-shape that follows successive intrusions to NW, outcropping as big slabs and rocky massifs, including the Pedra do Couto Hill. The rocks are dark gray in color (IC 6-8\%) inequigranular, medium-grained, with a slightly oriented structure. Triangular miarolitic cavities are present in some samples. Tabular perthitic to mesoperthitic alkali feldspar is predominant, usually with Carlsbad twinning and albitic borders. Quartz (2-3 vol\%) is interstitial, the largest crystals occasionally bearing mafic inclusions. Idiomorphic magnetite and ilmenite, biotite, titanite and zircon are associated and apatite is rare. Subidiomorphic to idiomorphic amphibole (greenish blue to bluish gray) occurs in some samples, partially replaced with biotite and carbonate. All mafic minerals show some post-magmatic alteration, titanite being replaced with calcite, ankerite, rutile and Ca-REE-fluorcarbonates (Fig. 8D). The same association fills miarolitic cavities.

\section{Anti-rapakivi quartz syenite}

This unit represents the neck-shape transition from the ring structure of the C-S to the NW-S, outcropping mainly as metric rounded boulders and small rocky hills and slabs. The rocks are rosy to brownish gray in color and medium to coarse-grained, being characterized by a massive anti-rapakivi porphyritic to glomeroporphyritic texture (Fig. 9B). Rounded biotite-rich enclaves (up to $30 \mathrm{~mm}$ ) occur to the southeast (Fig. 9C).

Plagioclase antecrysts $\left(\mathrm{An}_{25-30}\right)$ up to $20 \mathrm{~mm}$ wide are rounded to tabular. They are gray in color and usually mantled by white rims of alkali feldspar (Fig. 8E), and occasionally oscillatory zoned. Rounded, dark brown biotite (up to $10 \mathrm{~mm}$ ) with magnetite exsolution also occurs as possible antecrysts. The matrix is composed of subidiomorphic to idiomorphic mesoperthitic alkali feldspar that is interstitial to granophyric quartz (6-12 vol\%), biotite and aggregates of augite, titanomagnetite and titanite. Zircon, apatite and chevkinite are also associated. Ilmenite occurs as relicts partially replaced with titanite or associated with titanomagnetite.

\section{Trachytes I}

Trachytes occur in the transition from the C-S ring structure to NW-S, locally intercalated with arpk-QzS. On the basis of textural and mineralogical relationship, they can be grouped into four rock variants:

1. aphyric to porphyritic with aphanitic groundmass;

2. biotite-rich anti-rapakivi porphyritic with aphanitic groundmass;

3. porphyritic with fine-grained groundmass;

4. breccioid with aphanitic matrix.

Although the contact between these variants is not clear, some domains are topographically highlighted, with no lateral continuity among them. Changes are sudden or gradual over a few meters. 
Type (a) outcrops in the eastern part of the unit, from the north of the 5 Lagos Trail to Aiuruoca River Bog and, locally, to the west of the Morro da Antena Hill. These rocks are typically porphyritic with idiomorphic alkali feldspar $(2-10 \mathrm{~mm}), \pm$ plagioclase $(1-6 \mathrm{~mm}), \pm$ biotite $(1-2 \mathrm{~mm})$ and rare amphibole phenocrysts, with an aphanitic dark gray groundmass (Fig. 10A). To the west of Morro da Antena Hill and in easternmost part of the area, they occur as a fine-grained aphyric gray rock with rare alkali feldspar phenocrysts, cut by whitish veins.

Type (b) outcrops in the western and northern parts of the unit, especially on the trail to the Pedra Furada Hill. Typically, the rocks present aphanitic gray groundmass with rounded to idiomorphic zoned anti-rapakivi alkali feldspar (5-20 mm; very similar to arpk-QzS) and biotite (2-5 mm; Fig. 10B). Locally, it is aphyric, with rare alkali feldspar megacrysts.
Type (c) outcrops on a hill to the northeast of the Camelo's Rock and on the trail to the Pedra Furada Hill. The light brown rock resemble a fine variety of arpk-QzS, with the same anti-rapakivi texture. Mineralogy is similar, but with a presence of alkali feldspar megacrysts and reduced amount of plagioclase (Fig. 10C).

Type (d) is associated to (and sometimes intercalated with) Type (b). It outcrops near Camelo's Rock and along Carvoeiro Road and Flores' Highway to the south of Pedra Furada Hill, on Pedra Furada Hill summit, making up Morro da Antena Hill, on the top of a hill to the east portion and locally to the northwest portion. These rocks show an aphanitic matrix with millimetric to centimetric (locally more than 10 or $15 \mathrm{~cm}$ ) angular fragments of aphanitic to fine-grained rock, auto-fragments and alkali feldspar megacrysts (Fig. 10D). Fragments of coarse-grained rock are very rare. Notably, these variants can sometimes show fluidal textures with deformed fragments.
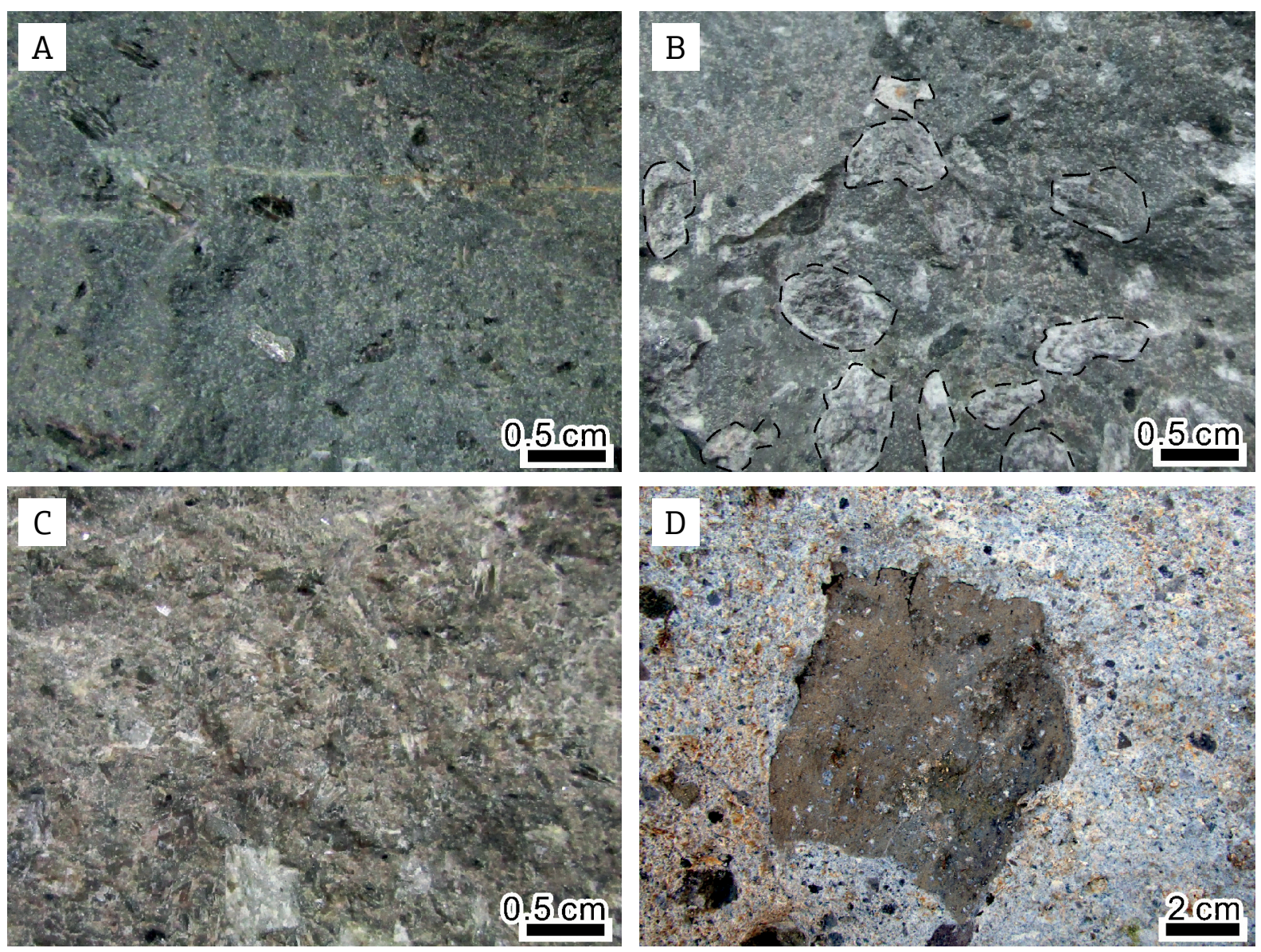

Figure 10. Representative macroscopic aspects of T-I rock facies in the Itatiaia Alkaline Massif. (A) Facies (a), MAI231. Porphyritic texture with alkali feldspar phenocrysts in aphanitic groundmass. (B) Facies (b), MAI118B. Porphyritic texture with plagioclase anti-rapakivi phenocrysts (highlighted by dashed lines) in aphanitic groundmass. (C) Facies (c), MAI113B. Porphyritic texture with fine-grained groundmass. (D) Facies (c), trail between MAI117C and 118. Aphanitic fragment in a breccioid rock with aphanitic matrix. 


\section{Northwestern Sector}

\section{Biotite monzonite}

These rocks were observed only in a small quarry at $\mathrm{km}$ 3.8 on Flores' Highway and as some rare centimetric angular xenoliths in arpk-QzS. They are massive, greenish gray in color and inequigranular, medium-grained (IC 23\%). They are characterized by their significant amount of poikilitic biotite, with cleavage planes but no preferential orientation.

Texture shows predominance of granular alkali feldspar and plagioclase ( $\mathrm{An}_{28-35}$; locally with partial reequilibration) in equal proportions, with augite and plagioclase enclosed in poikilitic dark brown biotite (Fig. 8 F). Plagioclase crystals larger than $2 \mathrm{~mm}$ usually show consertal texture, zoning, exsolution and inclusions of idiomorphic titanomagnetite and apatite. Subidiomorphic titanomagnetite and ilmenite usually intergrown. Ilmenite also occurs, as isolated xenomorphic crystals. Augite appears as subidiomorphic to xenomorphic grains, occasionally poikilitic (up to $1 \mathrm{~mm}$ ) and intergrown with plagioclase. Accessory phases include idiomorphic apatite ( $-3.2 \mathrm{vol} . \%)$ with fluid inclusions in core and xenomorphic zircon. Chlorite locally replaces biotite.

\section{Nordmarkite III}

This unit occurs on the northeastern border of NW-S, from the north of Pedra Furada Hill to the east of Fazenda Velha Town. The rocks are inequigranular, coarse to finegrained with massive to oriented structure. The mafic minerals usually are concentrated in patches and IC is about 8-9\%. Millimetric miarolitic cavities seldom occur.

Perthitic to mesoperthitic alkali feldspar (frequently with albitic border) is the most important mineral, showing a consertal texture of tabular to xenomorphic crystals, usually with polygonal interstices. Quartz (3-4 vol\%) is interstitial, seldom showing granophyric intergrowth. Subidiomorphic amphibole and idiomorphic ilmenite (commonly with a titanite corona) form irregular aggregates, which also contain biotite and \pm zircon. Biotite can form isolated subidiomorphic crystals in feldspar. Chevkinite and magnetite usually appear as xenomorphic to interstitial grains associated to quartz. Carbonate may fill cavities.

\section{Hornblende pulaskite}

This unit occurs along part of Flores' Highway and to the west of the road to Vargem Grande Town. It represents the first manifestation of silica-undersaturated rock from outer C-S inward. The rocks are inequigranular, slightly oriented and coarse-grained and are characterized by their light gray color (IC 5-25\%) with aggregates of mafic minerals (up to $10 \mathrm{~mm}$ ) and titanite crystals (up to $5 \mathrm{~mm}$; up to 2 vol\%).
These rocks are similar to those of $\mathrm{BtHblNeS}$ and $\mathrm{BtHblP}$ and are characterized by the presence of tabular mesoperthitic alkali feldspar, with local foyaitic texture. Nepheline is interstitial and reaches $12 \%$ modal volume in the northern region, while in the southern region (only up to 3 vol\%) it is almost completely replaced with analcime. Sodalite is interstitial. Plagioclase occurs locally, partially resorbed and re-equilibrated. Associated mafic minerals are idiomorphic to subidiomorphic diopside, which in the northern region occurs just as relics rimmed by magnesio-hastingsite, magnesio-hastingsite, titanite and titanomagnetite (Fig. 8G). Subidiomorphic biotite also occurs, as isolated crystals with feldspar. Main accessory minerals are zircon and apatite.

\section{Quartz alkali feldspar syenite III}

This is the unit with less information available, as access to the occurrence area is very limited. However, it is important for apparently forming a moon-shaped body emplaced between two nepheline-bearing units. It outcrops to the northeast of the Capivara River, between Garganta do Registro Pass and Engenho da Serra Town. These coarse-grained rocks are massive, brownish-gray (IC - 9\%) and inequigranular. Mesoperthitic alkali feldspars are present as subidiomorphic to xenomorphic grains with consertal texture, along with interstitial to granophyric quartz (11 vol\%) and biotite in subordinate amounts, with abundant apatite inclusions and magnetite exsolution, respectively. Subidiomorphic titanomagnetite with idiomorphic zircon, apatite and \pm biotite appear as milimeter-sized aggregates. Carbonates, chlorite and magnetite completely replace and/or alter subidiomorphic to interstitial pyroxene pseudomorphs.

\section{Nepheline syenite II}

This unit represents the last emplacement in the far northwest side of the plutonic units. It forms the Colina and Picú ridges, which are separated from each other by the Furnas River valley (Fazenda Velha Town), outcropping mainly as boulders.

These rocks are massive, coarse-grained, dark-gray (IC 6-10\%) and inequigranular, with tabular perthitic to mesoperthitic alkali feldspar, consertal texture and interstitial nepheline as main minerals. Locally, nepheline appears as aggregates of idiomorphic grains (up to $0.3 \mathrm{~mm}$ ) with polygonal texture (recrystallized?). Magnesio-hastingsite is present in some samples, with cores of diopside or biotite, clearly showing a complex instability relation, and subidiomorphic titanite (Fig. 8H). Locally, diopside appears as subidiomorphic or zoned grains, sometimes with thin rims of hedenbergite. A single grain of xenomorphic andradite associated with amphibole was found. Titanomagnetite is present as subidiomorphic rounded grains hosting very thin ilmenite exsolution lamellae, along with idiomorphic to 
subidiomorphic titanite. Accessory phases include sodalite, analcime, \pm hainite and \pm fluorite associated with small crystals of zircon (less than $0.05 \mathrm{~mm}$ ). Sphalerite, britholite, wöhlerite, allanite and scheelite are trace minerals.

Fine-grained to aphanitic aphyric dikes of trachytes and agpaitic phonolites also occur in this unit.

\section{Metasomatized melagabbro and trachybasalt}

These rocks represent the first record of mafic rocks in the Itatiaia massif along with nephelinite dykes in the southeastern border and rare xenoliths. They occur at two different spots, the first one as a few decimetric, rounded blocks in lower relief areas on the road that connects the Fazenda Velha and Colina towns, along NeS-II blocks to the west, mylonitic amphibolite to the north and covered by alluvium to the east. The second spot comprises abundant decimetric to metric tabular blocks on the northern hillside of the trail to Pedra do Picú.

MG-mts shows massive cumulatic texture, with color index of about $77 \%$ (Fig. 9D). However, these rocks have been altered by metasomatism and the original paragenesis appears to have been overprinted by post-magmatic replacement and/or recrystallization of the original phases. The cumulus consists of pyroxene pseudomorphs formed by aggregates of granular to xenomorphic ferro-pargasite, with interstitial magnetite, titanite, biotite and plagioclase (Fig. 8I). Locally, rounded cores of actinolite rimmed by high concentration ring of fine crystals of biotite, titanite, idiomorphic magnetite and amoeboid albite occur. Ilmenite is also present as xenomorphic grains rimmed by titanite and idiomorphic apatite (up to $2 \mathrm{~mm}$ ). The intercumulus is represented by xenomorphic plagioclase (relicts $A_{n} n_{37-44}$ and re-equilibrated $A n_{24-29}$ ) and albite with consertal texture, the latter locally and close to mafic minerals. Alkali feldspar is rare and occurs as idiomorphic crystals (up to $2 \mathrm{~mm}$ ) completely exsolved as very thin albite needles and a K-feldspar mass. Pyrite occurs as an accessory mineral.

$\mathrm{TB}$ is porphyritic, with idiomorphic phenocrysts $(1-4 \mathrm{~mm})$ of plagioclase $\left(\mathrm{An}_{45-50}\right)$, titanomagnetite and pseudomorph of pyroxene (replaced with chlorite and other unidentified minerals). The matrix is dark gray and very fine-grained, composed of acicular feldspar and pyroxene $(<0.2 \mathrm{~mm})$.

\section{Trachytes II}

These rocks occur in central NW-S and form the crest of the Picú Ridge. Its area of occurrence is possible overestimated because of the very limited access. The Pedra do Picú rock (a $120 \mathrm{~m}$ high landmark in the shape of a shark fin; Fig. 11A) consists of porphyritic trachyte, with alkali feldspar phenocrysts and a brownish aphanitic groundmass (Fig. 11B). A few sin-magmatic, irregular sub-horizontal aphyric dykes cut through their walls. About 100 meters to west, breccia is present with centimetric to decimetric angular fragments and auto-fragments. The fragments are aphanitic to fine-grained, while the matrix is strongly orientated in some places, with plastically deformed fragments (Fig. 11C).

In the eastern part of this unit, a different moon-shaped geomorphological feature showing rugged terrain and rocky hills is exposed. The only sample collected from the northern edge is characterized by a massive white variant, by the small grain size and by the porphyritic tendency. Large idiomorphic alkali feldspar crystals (up to $5 \mathrm{~mm}$ ) stand out in a fine-grained groundmass composed of alkali feldspar, quartz and opaque minerals.

\section{Sedimentary deposits}

Talus deposits occur in almost the entire massif border, especially in the southwestern region due to the steeper topographic gradient. The deposits are heterogeneous, ranging from decametric angular breccias boulders to conglomerates with centimetric clasts in the distal parts. Bauxite is also present, associated to talus and in vegetation-covered slopes in the nepheline-bearing units. At the Alambari River, the ramp of deposits extends for over $11 \mathrm{~km}$, with fluted erosion on some of the largest boulders. Three SW-NE elongated hills with $360 \mathrm{~m}$ thick talus are concentrated between the City of Itatiaia and the park entrance. There are evident piles of rolled blocks at C-S foothills. Rolled boulders also occur throughout the massif.

Alluvium deposits occur mainly over C-S form bogs in valleys and depressions (Fig. 11D). Such deposits are composed mainly of mud and peat, with coarser grains and centimetric clasts in the more proximal areas. The largest alluvia have its edges two to three meters above the current water level (Fig. 11E).

\section{PETROGRAPHIC SETS}

The lithological variants of Itatiaia Alkaline Massif can be divided into several clearly identifiable units based on mineralogical and petrographical features such as texture and modal variation of felsic and mafic minerals. A summary of crystallization sequence and paragenesis in the magmatic stages for each unit of the IAM are in Table 1. They comprise three main lithological variants: feldspathoid-bearing syenites, quartz-bearing syenites and basic rocks. These rocks can be distinguished in five petrographic sets (Fig. 12):

1. plagioclase-free nepheline syenites;

2. plagioclase-bearing nepheline syenite and pulaskites;

3. nordmarkite-granite series;

4. anti-rapakivi association;

5. basic rocks. 


\section{Nepheline-bearing syenites}

In general, the comparative mineralogy among nepheline-bearing syenites of all the IAM sectors indicates that all variants have similar paragenesis, with apatite, zircon, titanomagnetite, \pm ilmenite and diopside, alkali feldspar and nepheline. The textural and mineralogical variations permit to conclude that two crystallization pathways led to the generation of two sets:
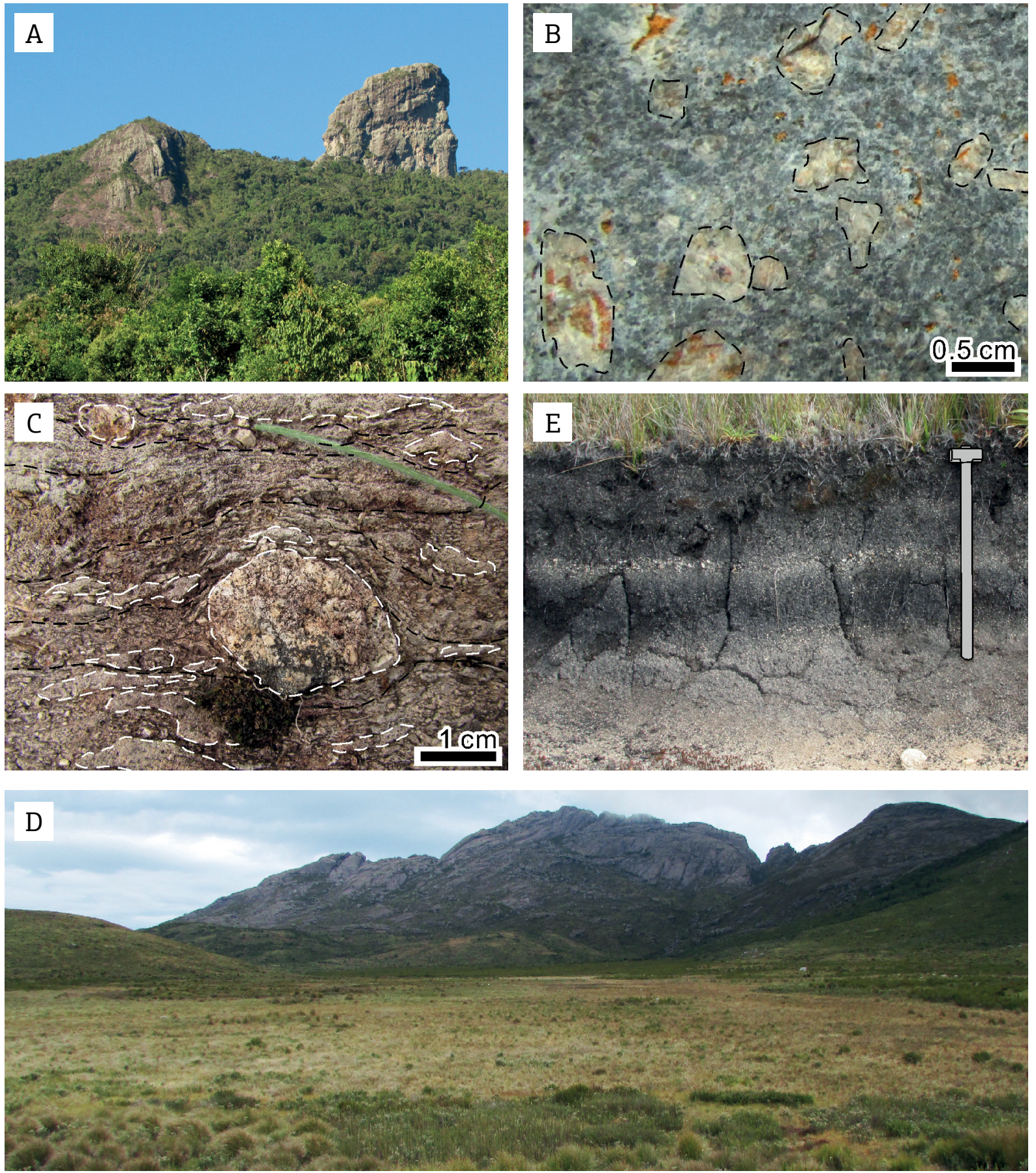

Figure 11. (A) Panoramic view to Pedra do Picú, right. (B) T-II, MAI165. Porphyritic texture with aphanitic groundmass and alkali feldspar phenocrysts. dashed lines. (C) Rocky hill at left of Pedra do Picú in A. Breccia with a very orientated groundmass and deformed fragments. Dashed lines highlight structure and contacts. (D) Panoramic View from Rancho Caído Trail. Preto River Bog in the C-S. Note the Agulhas Negras Peak (center) and Pedra do Sino Hill (right). (E) West side of the Aiuruoca River Bog. Typical alluvium deposit. 
Plagioclase-free (1): for NeS-I, SdlNeS, AegNeS-foy, SdlNeS and NeS-II units, which have sodic tendency, more silica-undersaturated (10-35\% foid modal) and more felsic (IC 5-16\%); pyroxene variation is represented by diopside $\rightarrow$ aegirine-augite $\rightarrow$ aegirine (except in NeS-II), low content of biotite, titanite, titanomagnetite and apatite and local presence of agpaitic minerals (låvenite, hiortdahlite and hainite, besides astrophyllite, rinkite, rosenbuschite and catapleiite). These minerals are dispersed throughout the rocks as interstitial phases and/ or aggregates of acicular crystals associated or replacing miaskitic minerals (aegirine-augite, ilmenite/titanomagnetite, zircon and biotite), whose presence of abundant sodalite indicates a transitional system from miaskitic to agpaitic rocks (Sørensen 1997, Marks et al. 2011, Andersen et al. 2016, Melluso et al. 2017). AegNeS-foy shows the highest levels of agpaitic minerals, while they are more abundant in facies of the southeastern border of NeS-I and crest areas of BtAgtNeS. Agpaitic rocks in the external areas of ring complexes also occur in other

Table 1. Crystallization sequence of plutonic units and paragenesis of magmatic stages of the Itatiaia Alkaline Massif. Volume percent of feldspathoid or quartz, respectively (Foid or Qz), index color, total mafic mineral volume percent (IC). Character formatting denotes modal content: principal ( $>10 \%$, bold); accessory $(1<\%<10$, normal case); trace (<1, italics). Local paragenesis [ ]; replacement associations ( ); antecrysts \{ $\}$; absence of clinopyroxene (Cpx, striked). Unit abbreviations are the same as those of Figure 2.

\begin{tabular}{|c|c|c|c|c|c|c|c|}
\hline & Unit & $\begin{array}{l}\text { Foid } \\
\text { or } Q z\end{array}$ & IC & Early & Main & Late & Post \\
\hline \multirow{4}{*}{ 岂 } & NeS-I & $30-35$ & $5-6$ & Tmt, Ttn, Ap & $\begin{array}{c}\text { Agt, } \mathbf{N e}, \mathbf{A f s} \\
{[\in \mathrm{p} x, \mathbf{P l}, \mathrm{Her}, \mathrm{Crd}, \mathrm{Rt}]}\end{array}$ & $\begin{array}{l}\text { Aeg, Sdl, Hio, [Kup], } \\
\text { Pcl, (Amp, Bt), Anl }\end{array}$ & $\mathrm{Ccn}, \mathrm{Cat}, \mathrm{Cb}, \mathrm{Ms}$ \\
\hline & BtHblNeS & $5-15$ & $8-20$ & $\{\mathrm{Pl}\}, \mathrm{Ap}, \mathrm{Zrn}, \mathrm{Tmt}, \mathrm{Di}$ & Afs, Ttn, Ne, Mhst & $\mathrm{Bt}, \mathrm{Sdl}$ & Ccn \\
\hline & SdlNeS & $10-15$ & $5-12$ & $A p, Z r n, T m t, D i$ & Ttn, Ne, Afs, Agt, Sdl & Bt, Låv, Pcl, Flu, Amp & $\mathrm{Cb}$ \\
\hline & AegNeS-foy & 30 & 9 & $A p, Z r n, T m t, \mathbf{N e}$ & Afs, Ttn, Aeg, Ilm, Bt & $\begin{array}{l}\text { Låv, Arf, Sdl, Ang, } \\
\text { Ast, Flu }\end{array}$ & \\
\hline \multirow{9}{*}{ ú } & BtAgtNeS & $8-25$ & $12-20$ & Ap, Zrn, Tmt, Ilm & Afs, Ttn, Ne, Agt & $\begin{array}{l}\text { Aeg, Bt, Sdl, [Låv, Arf, } \\
\text { Rnk, Rsb, Sp] }\end{array}$ & \\
\hline & BtP & $0-5$ & $11-22$ & $\begin{array}{l}\{\mathrm{Pl}\}, A p, \mathrm{Tmt} \\
I l m, \mathrm{Di}, \mathrm{Zrn}\end{array}$ & Afs, Mhst, Ttn & $\begin{array}{c}\text { Zcl, Py, Gn, Ne, Sdl, Bt, } \\
\text { Hst, Flu, Anl }\end{array}$ & \\
\hline & AegN & $3-4$ & $9-10$ & $\mathrm{Zrn}, \mathrm{Tmt}, \mathrm{Ilm}$ & Afs, Agt, Cvk & $\mathrm{Qz}, \mathrm{Aeg}, \mathrm{Ab}, \mathrm{Py}, \mathrm{Pcl}$ & $\begin{array}{c}\text { (Ank, Flu, } \\
\text { REE-Fcb, Ilm) }\end{array}$ \\
\hline & N-I & $2-4$ & $9-11$ & $\begin{array}{l}\{P l\}, A p, Z r n, \\
\text { Tmt, Ilm, Aug }\end{array}$ & Afs, Ttn, Agt & Rct, Bt, Qz & \\
\hline & QzAFS-I & $5-8$ & $9-11$ & Zrn, Ilm, Ap, Agt & Tmt, Frct, $C v k$, Afs, Ttn & $\mathrm{Qz}, \mathrm{Bt}$ & \\
\hline & QzAFS-II & $12-18$ & $7-10$ & $A p, Z r n$, Tmt, Ilm & Amp, Afs, Bt, Cvk & Qz, Bt, [Flu, Aln], Ab & {$[\mathrm{Cb}]$} \\
\hline & $\mathrm{mA}$ & 26 & 5 & $A p, Z r n, T m t$ & Afs, $P c l$, Qz, Flu & $\mathrm{C} v k, \mathrm{Bt}, \mathrm{Mnz}, \mathrm{Xtm}, \mathrm{Ab}$ & $\mathrm{Cb}$ \\
\hline & N-II & $2-3$ & $6-8$ & $A p, \mathrm{Zrn}, \mathrm{Ilm}, \mathrm{Tmt}$ & $\mathrm{Di}, \mathrm{Ttn}, \mathbf{A f s}$ & $\mathrm{Qz}, \mathrm{Bt}, \mathrm{Cvk}, \mathrm{Ab}, \mathrm{Ank}$ & $\begin{array}{l}\text { (Cal, Ank, Rt, } \\
\text { REE-Cb) }\end{array}$ \\
\hline & arpk-QzS & $6-12$ & $6-10$ & $\begin{array}{c}\{\mathbf{P l}, \mathrm{Bt}\}, A p, Z r n, I l m \\
\text { Tmt, } D i\end{array}$ & Cvk, Afs, Aug, Ttn & Bt, Qz & \\
\hline \multirow{6}{*}{$\sum_{z}^{\infty}$} & N-III & $3-4$ & $8-9$ & Zrn, Ilm, Aug & Afs, Tmt, Ttn, Amp, Bt & $\mathrm{Cvk}, \mathrm{Qz}, \mathrm{Ab}$ & $\mathrm{Cb}$ \\
\hline & BtM & - & 23 & Ap, Ilm, Tmt & Zrn, Aug, Pl, Afs & $\mathrm{Bt}$ & Chl \\
\hline & MG-mts & - & 77 & Ap, Ilm & Epx, Pl & $P y$, Ttn & $\begin{array}{l}\text { (Fprg, Mt, } \\
\text { Ttn, Bt)? }\end{array}$ \\
\hline & HblP & $3-12$ & $9-18$ & $\{P l\}, A p, Z r n, T m t, D i$ & Afs, Ttn, Ne, Mhst & Bt, Hst, Sdl, Anl & Ccn \\
\hline & QzASF-III & 9 & 11 & $A p, Z r n$ & Ttn, Cpx, Afs, Bt & $\mathrm{Qz}$ & \\
\hline & NeS-II & $10-15$ & $6-10$ & $A p, A d r, T m t, A l n, D i$ & Afs, $\mathbf{N e}, H d$, Mhst, Ttn & $\begin{array}{l}\text { Bt, Hst, Hai, Sdl, Zrn, } \\
\text { Flu, Brt, Sp, Shl, Anl }\end{array}$ & \\
\hline
\end{tabular}

Ab: albite; Adr: andradite; Aeg: aegirine; Afs: alkali feldspar; Agt: aegirine-augite; Aln: allanite; Amp: amphibole; Ang: aenigmatite; Ank: ankerite; Anl: analcime; Ap: apatite; Arf: arfvedsonite; Ast: astrophyllite; Aug: augite; Brt: britholite; Bt: biotite; Cal: calcite; Cat: catapleiite; Cb: carbonate; Ccn: cancrinite; Chl: chlorite; Cpx: clinopyroxene; Crd: corundum; Cvk: chevkinite; Di: diopside; Flu: fluorite; Fprg: ferro-pargasite; Frct: ferro-richterite; Gn: galene; Hai: hainite; Hst: hastingsite; Hbl: hornblende; Her: hercynite; Hio: hiortdahlite; Ilm: ilmenite; Kup: kupletskite; Låv: låvenite; Mhst: magnesio-hastingsite; Mnz: monazite; Ms: muscovite; Mt: magnetite; Ne: nepheline; Pcl: pyrochlore; Pl: plagioclase; Py: pyrite; Qz: quartz; Rct: riebeckite; REE-Cb: REE-carbonate; REE-Fcb: REE-fluorcarbonate; Rnk: rinkite; Rsb: rosenbuschite; Rt: rutile; Sdl: sodalite; Shl: scheelite; Sp: sphalerite; Tmt: titanomagnetite; Ttn: titanite; Xtm: xenotime; Zcl: zirconolite; Zrn: zircon. 
localities, e.g., Poços de Caldas (Ulbrich 1993) and Pilanesberg (Andersen et al. 2016), interpreted as late manifestations and related to caldera system collapse;

- Plagioclase-bearing (2): BtHblNeS, BtHblP and HblP show a potassic-calcic tendency, lower silica-undersaturation $(0-15 \%$ foid modal), higher mafic content (IC 10-28\%), diopside relics rimmed by magnesio-hastingsite, high content of biotite, titanite, titanomagnetite and apatite and presence of plagioclase, usually with anti-rapakivi texture. The largest plagioclase crystals show the highest An (40-50\%) and their cores are less re-equilibrated. The presence of plagioclase and diopside with replacement textures, lower foid content and higher IC could indicate interaction with a more basic magma in an early stage. However, mafic enclaves or any suggestive texture were not found.

Alternations of nepheline syenite types indicate changes in intensive parameters $\left(\mathrm{O}_{2}, a \mathrm{H}_{2} \mathrm{O}, a \mathrm{SiO}_{2}\right)$ and magmatic processes such as magma mixing, different degrees of contamination and fractioning of mafic minerals in a resident chamber. These rock sets bear similarities with SA and A types, respectively, as described by Brotzu et al. (1997), who interpreted A type as predominant and SA-types as later intrusions. In the present study, we observed that both these types are intercalated in SE-S. In C-S, Pl-free composes the external ring and the Pl-bearing internally, while they do not have contact relations in the NW-S, though Pl-bearing occurs first and the $\mathrm{Pl}-\mathrm{free}$ is the youngest plutonic unit of the massif.

\section{Quartz-bearing syenites}

Quartz-bearing rocks occur in inner C-S without contact with the country rocks, in the transition from C-S to NW-S and across NW-S. They typically exhibit post-magmatic

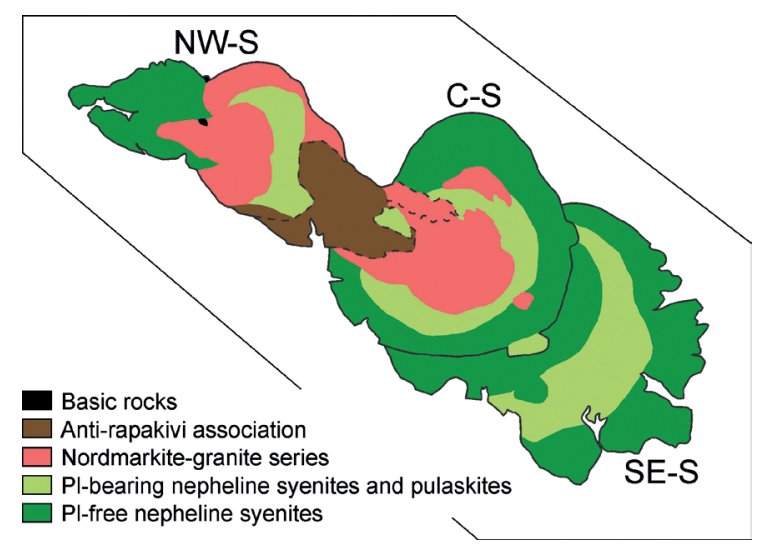

Figure 12. Simplified map of the Itatiaia alkaline massif (Fig. 2) showing its Southeastern, Central and Northwestern sectors and their petrological sets. replacement features, with largely sericitized feldspar and mafic phases replaced with oxides, carbonates or fluorcarbonates. Almost all units show miarolitic cavities. Two sets were identified based on mineralogy and texture:

Nordmarkite-granite series (3): AegN, N-I, N-II, N-III, QzAFS-I, QzAFS-II, QzAFS-III and mA had similar initial paragenesis, with \pm apatite, zircon, \pm ilmenite, titanomagnetite, augite/aegirine-augite and alkali feldspar. In these units, quartz initiates the crystallization in different magmatic stages, with variations in modal volume, grain size and texture. The presence of clinopyroxene and amphibole is variable, with units in which amphibole is absent (AegN and N-II), or clinopyroxene is replaced (N-I, QzAFS-I and N-III), or lacks clinopyroxene (QzAFS-II) or are both absent $(\mathrm{mA})$, probably resulting from particular variation of $f \mathrm{O}_{2}$ and $a \mathrm{H}_{2} \mathrm{O}$ during evolution. The nordmarkite occurrences do not show a clear evolutive relation among themselves, since they are not in contact with each other, while QzAFS-I, QzAFS-II and $\mathrm{mA}$ are apparently in direct connection. T-I(a) and T-II also bear mineralogical similarities with this series, although they formed in a different geological context. T-II intrudes the central part of NW-S and constitutes the Pedra do Picú, possibly representing a well-preserved volcanic neck;

- Anti-rapakivi association (4): the relation among arpk-QzS, $\mathrm{T}-\mathrm{I}(\mathrm{b})$ and $\mathrm{T}-\mathrm{I}(\mathrm{c})$ is a very close one: all of them exhibit the same anti-rapakivi porphyritic tendency in appearance and mineralogy (Figs. 9B and 10B). In the field, in most cases it is very difficult to establish their limits, that are sometimes either abrupt or gradual. arpk-QzS has a characteristic glomeroporphyritic anti-rapakivi texture, locally containing two types of mafic enclaves: a rounded one, very fine-grained and aphyric, similar to that of T-I(b) and an rounded to irregular fine-grained one that resembles BtM xenoliths (Fig. 9C), given that their petrography is the same (biotite inclusion in plagioclase renders the same poikilitic texture of BtM). These structural and textural features suggest magma mixing adjacent to the west portion, where one of the components could be BtM.

\section{Basic rocks}

- Melagabbric to trachybasaltic rocks (5): other minor rock types of the Itatiaia Alkaline Massif (MG-mts and TB) show unclear geological connections with the syenitic rocks. MG-mts could stand for an older and/or deeper portion of the chamber brought to a shallow level by tectonic-magmatic processes, although field relations do not allow such an assertion. Cumulatic gabbros occur in a few localities in Serra do Mar Province, e.g., Ponte Nova (Azzone et al. 2009) and Morro de São João (Brotzu et al. 2007), but this is their first description in IAM. 
$\mathrm{TB}$ is the last magmatic manifestation of the IAM and apparently intrudes T-II. It bears mineral similarities to MG-mts and they could be connected.

\section{GEOLOGICAL EVOLUTION}

Magmatism in the IAM (71.3 to 67.5 Ma, Rosa 2017) followed a regional uplift that took place from 90 to $75 \mathrm{Ma}$ and was over before tectonic collapse and development of the Continental Rift of Southeastern Brazil 55 to $40 \mathrm{Ma}$ ago (Riccomini 1989, Zalán \& Oliveira 2005, Cogné et al. 2011, 2012, Engelmann de Oliveira et al. 2016, Salgado et al. 2016). The massif is adjacent to Resende Basin and was emplaced near the Queluz Accommodation Zone, which separates Paraíba do Sul Rift into two different tectonic patterns (Zalán \& Oliveira 2005). It stands out as a remarkable elongated topographic structure, one of the few elongated ones in the province and the only one oriented to WNW (Fig. 2), which is in accordance with the accommodation zones of the rift system and the transfer zones of the South Atlantic Ocean Plate (Meisling \& Cob 2001, Zalán \& Oliveira 2005, Cogné et al. 2012, Stanton et al. 2014, Negrão et al. 2015).

A tension relief due to regional uplift could have progressively changed the accommodation zone (like a zip fastening), causing migration of the decompression zone and the partial melting that resulted in magma generation. The IAM was then formed as a result of the evolution a migratory magmatic center, as successive moon-shape intrusions for over $30 \mathrm{~km}$ along an axis oriented from southeast to northwest, with ring structures arranged into three sectors with distinct lithological and geomorphological characteristics: Southeastern, (SE-S), Central (C-S) and Northwestern (NW-S). IAM is one of the few ring complexes whose origin involved migration of a magmatic center (e.g. Wadi Dib, Egypt; Frisch \& Abdel-Rahman 1999; Ras ed Dom, Sudan, O'Halloran 1985). This characteristic of the massif permitted good preservation and clear distinction of magmatic pulses, since previous intrusions were not mixed and/or erased.

\section{Emplacement stages}

The lithological variants can be divided into several clearly identifiable facies based on mineralogical and petrographical features, such as texture and modal variation of felsic and mafic mineral content. They include feldspathoid-bearing or quartz-bearing syenites, trachytes, granite, monzonite, gabbro and trachybasalt, resulting in 21 units that represent the different magmatic pulses. Sin- to tardi-plutonic dykes of nephelinites, phonolites, trachytes and rhyolites are also present.

The early magmatic intrusions (first stage) are represented by alkaline rock-types in SE-S and are almost entirely emplaced into CRSB. Apparently, SE-S was not strongly affected by the development of the rift system, as its rocks do not show expressive magmatic foliation nor have been deformed into shear zones, which suggests that they intruded their hosts as most liquid magma, without undergoing crystallization under significant stress conditions. Apparently, the radial lineament pattern in the northern and eastern regions is post-magmatic. Although migration to NW was already present, it is not clear if a temporal gap occurred between the emplacement of SE-S and C-S, although suggested by the morphological and petrographical setting.

$\mathrm{NeS}-\mathrm{I}$ is the most silica-undersaturated unit and it has garnet-sillimanite-muscovite-biotite schists of the Embú Group in Ribeira Belt as wall rocks (Eirado et al. 2006, Heilbron et al. 2016). Assimilation of peraluminous minerals could have led to crystallization of corundum and hercynite in such a silica deficient magma. The association of plagioclase, hercynite and corundum found in these rocks could suggest garnet rebalancing (Mariga et al. 2006). Mafic microgranular enclaves is also common in peraluminous samples (Figs. 6A and 6B). The fine-grained inner varieties of this facies could represent small stocks, but their fieldwork control is very difficult due to vegetation and topography. Evidence of assimilation from wall rock units was not found in other plutonic units.

The second stage emplaced a large silica-undersaturated intrusion of BtAgtNeS in Central IAM. The peralkaline facies makes up the crest of the circular ridge. This variant, that could correspond to a late magmatic stage, do not show any evidence of caldera subsidence. The trachytic sin-plutonic dikes could be related to the intrusion of $\mathrm{BtHblP}$. This magma pulse is similar to the SE-S cluster, but the subsequent one evolved with an increase in silica content and, in some way, crossed the thermal barrier of nepheline-quartz to the silica-oversaturated types. Isotopic data shows crustal contamination in quartz-bearing rocks (Brotzu et al. 1997, Rosa 2017). The first C-S intrusions are concentric, but QzASF-II resumed migration to NW.

The quartz-bearing rocks do not show clear evolutive relations among themselves. AegN and N-I intrude between BtAgtNeS and BtHblP and are possibly the first $\mathrm{SiO}_{2}$-supersaturated manifestation. N-II occurs in a similar location, although in a certainly younger geological relation. QzAFS-I and -II and their internal facies apparently show a weak gradational increase in quartz content and orientation with a decrease in granulation and color index to the northwest. $\mathrm{mA}$ is the most evolved quartz-bearing unit of the massif. It intrudes QzAFS-II, although no contact has been observed between them. It is possibly a product of QzAFS-II internal differentiation contemporary to the rhyolite dikes. $\mathrm{mA}$ shape and location suggest development linked to the VLL, as evidenced by the strong parallel fracturing and the frequent quartz veins, however it has a massif structure. On the 
other hand, the presence of miarolitic cavities, especially in QzAFS-I, may suggest relatively shallow crystallization.

The transition between C-S and NW-S is marked by arpk-QzS and T-I, but their temporal relation is not clear and they apparently intrude part of N-III. NW-S represents a third stage, since geological features and lithotype associations change in both sectors, the caldera-shaped structure fades away and the magmatic center resumes migration, with intrusions similar to SE-S. There is no sufficient information on the quartz-bearing rocks of NW-S. The location and some textures of N-III and QzAFS-III (e.g. magmatic orientation of N-III and both presenting mafic agglomerates) could suggest that they are border facies of HblP with large country rock assimilation. But this is unlikely, since they are similar in extension and HblP gradates (increase in the nepheline, amphibole and titanite content) northward. NeS-II was the last plutonic unit to emplace and bears great textural similarities with NeS-I, although it has amphibole as a late magmatic phase instead of aegirine.

T-I(d), T-II and TB could represent a fourth magmatic stage, corresponding to subvolcanic conducts with epigenetic characteristics, as suggested by aphanitic auto-fragments and locally fluidal deformation.

\section{FINAL REMARKS}

Based in petrography, field observations, body geometry and remote sensing information, new insights are presented into the geology and magmatic evolution of Itatiaia Alkaline Massif, along with the proposition of a new geological map and emplacement model.

The IAM forms a WNW elongated ring complex emplaced into an accommodation zone during the development of the Continental Rift of Southeastern Brazil, which is in accordance with transfer zones of South Atlantic Ocean plate. The IAM resulted from a migratory magmatic center manifested as successive moon-shape intrusions disposed from SE to NW as ring structures, in three sectors of distinct lithological and geomorphological characteristics, which could be related to different origin and/or evolution stages: Southeastern Sector consists of miaskitic to agpaitic nepheline syenites with dykes of aphiric, porphyritic (some with pseudoleucite) and breccioid phonolites and nephelinites. Its most silica-undersaturated units are in contact with the basement, being locality peraluminous with modal hercynite and corundum. The C-S is represented by miaskitic to agpaitic nepheline syenites, pulaskites, nordmarkites, quartz alkali feldspar syenites, a small alaskite body and porphyritic to breccioid trachytes. Sin-plutonic trachytes sustain the external ring and dykes of trachyte and rhyolite occur throughout this sector. The Northwestern Sector presents nepheline syenites and nordmarkites and locality cumulatic melagabro and biotite monzonite. In its central parts, porphyritic to breccioid trachytes and a trachybasalt body occur.

The lithological variants can be divided into several clearly identifiable units based on mineralogical and petrographical characteristics such as textures and modal variation of felsic and mafic minerals. They include feldspathoid-bearing and quartz-bearing syenites, trachytes, granite, monzonite, gabbro and trachybasalt, forming 21 units that represent different magmatic pulses. Sin- to tardi-plutonic dykes of nephelinites, phonolites, trachytes and rhyolites also occur. These rocks correspond to five petrographic sets:

1. plagioclase-free nepheline syenites, characterized by strong silica-undersaturation and late agpaitic tendency (commonly with låvenite, hiortdahlite and/or rinkite);

2. plagioclase-bearing nepheline syenite and pulaskite showing weak silica-undersaturation and increased mafic content, with widespread diopside replaced with magnesio-hastingsite and presence of plagioclase (usually with anti-rapakivi texture);

3. nordmarkite-granite series in which alkali feldspar quartz syenite and granite show progressive variation in quartz content, color index and granulation, whereas nordmarkites do not show a clear common evolution;

4. a quartz syenite association characterized by anti-rapakivi porphyritic to glomeroporphyritic texture and occasional presence of rounded mafic enclaves;

5. basic rocks represented by metasomatized melagabbro and trachybasalt, with an unclear geological relation to the syenites.

\section{ACKNOWLEDGMENTS}

Thank you Michael Marks, Rogério Guitarrari Azzone and Gaston Eduardo Enrich Rojas for the discussions! Thanks a lot for the fieldworks help, Bruna Miraya, Caio Santos (2x!), Claudio Mora, Emanuel Amorer, Geovanne Moreira, Igor Barboza, Julio Cauhy, Lucaz Inglez, Ludmila Teixeira, Maria Paula Ramos, Matheus Caseri, Pedro Angelini, Rafael Capelle, Rafaela Gengo and Saulo Vieira! Thanks to FAPESP for the financial support (Processes 2012/19184-1, 2012/06082-6 and 2015/19974-0). Thanks to the Itatiaia National Park for the logistical support, permissions and directions, especially to Gustavo Tomzhinski, Léo Nascimento, Leonardo Cândido and Marcão's station staff.

Congratulations to the Itatiaia National Park for its 80 years of existence!

\section{SUPPLEMENTARY DATA}

Supplementary data associated with this article can be found in the online version: Supplementary Table A1. 


\section{REFERENCES}

Algarte J.P. 1972. A Influência dos Arqueamentos Cratônicos no Condicionamento das Alcalinas dos Estados de São Paulo e Paraná. In: Congresso Brasileiro de Geologia. Belém: SBG - Sociedade Brasileira de Geologia, p. 65-69.

Almeida F.F.M. de 1967. Origem e evolução da Plataforma Brasileira. Rio de Janeiro, Divisão de Geologia e Mineralogia. Boletim, 241.

Almeida F.F.M. de 1969. Diferenciação tectônica da plataforma brasileira. In: Congresso Brasileiro de Geologia. Salvador: SBG Sociedade Brasileira de Geologia, p. 29-46.

Almeida F.F.M. de 1971. Condicionamento tectônico do magmatismo alcalino mesozóico do Sul do Brasil e do Paraguai ocidental. Anais da Academia Brasileira de Ciências, 43:835-836.

Almeida F.F.M. de 1976. The system of continental rifts bordering the Santos Basin, Brazil. Anais da Academia Brasileira de Ciências, 48:15-26.

Almeida F.F.M. de 1983. Relações tectônicas das rochas alcalinas mesozóicas da região meridional da plataforma sul-americana. Revista Brasileira de Geociências, 13:139-158.

Almeida F.F.M. de 1991. O Alinhamento Magmático de Cabo Frio. In: Simpósio de Geologia do Sudeste, 2. São Paulo: SBG - Sociedade Brasileira de Geologia/SP-RJ, p. 423-428

Almeida F.F.M. de, Carneiro C.D.R., Mizusaki A.M.P. 1996. Correlação do magmatismo das bacias da margem continental brasileira com o das áreas emersas adjacentes. Revista Brasileira de Geociências, 26:125-138.

Alves A., Janasi V. de A., Campos Neto M. da C. 2016. Sources of granite magmatism in the Embu Terrane (Ribeira Belt, Brazil): Neoproterozoic crust recycling constrained by elemental and isotope (Sr-Nd-Pb) geochemistry. Journal of South American Earth Sciences, 68:205-223. DOI: 10.1016/j.jsames.2015.10.014

Alves A., Pereira G. de S., Janasi V. de A., Higgins M., Polo L.A., Juriaans O.S. \& Ribeiro B.V. 2015. The origin of felsic microgranitoid enclaves: Insights from plagioclase crystal size distributions and thermodynamic models. Lithos, 239:33-44. DOI: 10.1016/j.lithos.2015.09.027

Andersen T., Elburg M., Erambert M. 2016. The miaskitic-to-agpaitic transition in peralkaline nepheline syenite (white foyaite) from the Pilanesberg Complex, South Africa. Chemical Geology. DOI: 10.1016/j.chemgeo.2016.08.020

Azzone R.G., Ruberti E., Rojas G.E.E., Gomes C. de B. 2009. Geologia e Geocronologia do Maciço Alcalino Máfico-Ultramáfico Ponte Nova (SP-MG). Geologia USP. Série Científica, 9:23-46. DOI: 10.5327/ Z1519-874X2009000200002

Bellieni G., Montes-Lauar C.R., De Min A., Piccirillo E.M., Cavazzini G., Melfi A.J., Pacca I.G. 1990. Early and Late Cretaceous magmatism from São Sebastião Island (SE-Brazil): geochemistry and petrology. Geochimica Brasiliensis, 4:59-83. DOI: 10.21715/gb.v1i4.31

Bennio L., Brotzu P., D’Antonio M., Feraud G., Gomes C.B., Marzoli A., Melluso L., Morbidelli L., Morra V., Rapaille C., Ruberti E. 2003. The tholeiitic dyke swarm of the Arraial do Cabo peninsula (SE Brazil): $39 \mathrm{Ar} / 40 \mathrm{Ar}$ ages, petrogenesis, and regional significance. Journal of South American Earth Sciences, 16:163-176. DOI: $10.1016 /$ S0895-9811(03)00030-0

Brade A.C. 1956. A Flora do Parque Nacional. Boletim do Parque Nacional do Itatiaia, 5:1-111

Brotzu P., Gomes C.B., Melluso L., Morbidelli L., Morra V., Ruberti E. 1997. Petrogenesis of coexisting SiO2-undersaturated to SiO2oversaturated felsic igneous rocks: The alkaline complex of Itatiaia, southeastern Brazil. Lithos, 40:133-156. DOI: 10.1016/ S0024-4937(97)00007-8
Brotzu P., Melluso L., Bennio L., Gomes C.B., Lustrino M., Morbidell L., Morra V., Ruberti E., Tassinari C., D’Antonio M. 2007. Petrogenesis of the Early Cenozoic potassic alkaline complex of Morro de São João, southeastern Brazil. Journal of South American Earth Sciences, 24:93-115. DOI: 10.1016/j.jsames.2007.02.006

Brotzu P., Melluso L., D’Amelio F., Lustrino M. 2005. Mafic/ultramafic dykes and felsic intrusions with potassic to ultrapotassic affinity in the Serra do Mar province: a review. In: Comin-Chiaramonti P. \& Gomes C.B. (eds.), Mesozoic to Cenozoic alkaline magmatism in the Brazilian Platform. São Paulo, EDUSP-FAPESP, p. 443-472.

Campos Neto M.D.C., Basei M.A.S., Assis Janasi V. de, Moraes R. 2011. Orogen migration and tectonic setting of the Andrelândia Nappe system: An Ediacaran western Gondwana collage, south of São Francisco craton. Journal of South American Earth Sciences, 32:393-406. DOI: 10.1016/j.jsames.2011.02.006

Carvalho B.B., Janasi V. de A., Henrique-Pinto R. 2014. Geochemical and $\mathrm{Sr}-\mathrm{Nd}-\mathrm{Pb}$ isotope constraints on the petrogenesis of the K-rich Pedra Branca Syenite: Implications for the Neoproterozoic post-collisional magmatism in SE Brazil. Lithos, 205:39-59. DOI: 10.1016/j.lithos.2014.06.016

Cawthorn R.G. 2015. The geometry and emplacement of the Pilanesberg Complex, South Africa. Geological Magazine, 152:802-812. DOI: 10.1017/S0016756814000764

Chiessi C.M. 2004. Tectônica cenozóica do Maciço Alcalino de Passa Quatro (SP-MG-RJ). Dissertation, Instituto de Geociências, Universidade de São Paulo, São Paulo, 116 p. DOI: 10.11606/D.44.2004.tde-10042014-161924

Cioff C.R., Campos Neto M.C., Moeller A., Rocha B.C. 2015 Paleoproterozoic continental crust generation events at 2.15 and $2.08 \mathrm{Ga}$ in the basement of the southern Brasília Orogen, SE Brazil. Precambrian Research, 275:176-196. DOI: 10.1016/j. precamres.2016.01.007

Cogné N., Gallagher K., Cobbold P.R. 2011. Post-rift reactivation of the onshore margin of southeast Brazil: Evidence from apatite (U-Th)/He and fission-track data. Earth and Planetary Science Letters, 309:118-130. DOI: 10.1016/j.epsl.2011.06.025

Cogné N., Gallagher K., Cobbold P.R., Riccomini C., Gautheron C. 2012 Post-breakup tectonics in southeast Brazil from thermochronological data and combined inverse-forward thermal history modeling. Journal of Geophysical Research: Solid Earth, 117(B11):413. DOI: 10.1029/2012JB009340

Comin-Chiaramonti P., Gomes C.B., De Min A., Ernesto M., Gasparon M. 2015. Magmatism along the high Paraguay River at the border of Brazil and Paraguay: A review and new constraints on emplacement ages. Journal of South American Earth Sciences, 58:72-81. DOI 10.1016/j.jsames.2014.12.010

Eirado L.G., Heilbron M., Almeida J.C.H. 2006. Os Terrenos Tectônicos da Faixa Ribeira na Serra da Bocaina e na Baía da Ilha Grande, Sudeste do Brasil. Revista Brasileira de Geociências, 36:426-436.

Engelmann de Oliveira C.H., Jelinek A.R., Chemale F., Cupertino J.A. 2016. Thermotectonic history of the southeastern Brazilian margin: Evidence from apatite fission track data of the offshore Santos Basin and continental basement. Tectonophysics, 685:21-34. DOI: 10.1016/j.tecto.2016.07.012

Enrich G.E.R., Azzone R.G., Ruberti E., Gomes C.B., Comin-Chiaramonti P 2005. Itatiaia, Passa Quatro and São Sebastião island, the major alkaline syenitic complexes from Serra do Mar region. In: Comin-Chiaramonti P., Gomes C.B. (eds.), Mesozoic to Cenozoic alkaline magmatism in the Brazilian Platform. São Paulo: EDUSP-FAPESP, p. 419-442. 
Enrich G.E.R., Ruberti E., Gomes C.B. 2009. Geology and geochronology of Monte de Trigo island alkaline suite, southeasern Brazil. Revista Brasileira de Geociências, 39:67-80.

Ferrari A.L. 2001. Evolução Tectônica do Graben da Guanabara. Thesis, Instituto de Geociências, Universidade de São Paulo, São Paulo, 412 p. DOI: 10.11606/T.44.2001.tde-29082013-152530

Foland K.A., Landoll J.D., Henderson C.M.B., Chen J. 1993. Formation of cogenetic quartz and nepheline syenites. Geochimica et Cosmochimica Acta, 57:697-704. DOI: 10.1016/0016-7037(93)90380-F

Frisch W., Abdel-Rahman A.M. 1999. Petrogenesis of the Wadi Dib alkaline ring complex, Eastern Desert of Egypt. Mineralogy and Petrology, 65:249-275. DOI: 10.1007/BF01161963

Gomes C.B., Comin-Chiaramonti P. 2005. An introduction to the alkaline and alkaline-carbonatitic magmatism in and around the Paraná-Basin. In: Comin-Chiaramonti P., Gomes C. (eds.), Mesozoic to Cenozoic alkaline magmatism in the Brazilian Platform. São Paulo, EDUSP-FAPESP, p. 21-30.

Gomes C.B., Valarelli J.V. 1970. Nova ocorrência de rochas alcalinas no Estado de São Paulo. In: Congresso Brasileiro de Geologia, 24. Brasília: SBG - Sociedade Brasileira de Geologia, p. 336-337.

Google Earth. 2015. Itatiaia National Park, Brazil, 22021'S, 44041'. Astrium, 8/30/2013. Available from: <http://www.earth.google. com>. Acessed on: June 30, 2015.

Guarino V., Azzone R.G., Brotzu P., de Barros Gomes C., Melluso L., Morbidelli L., Ruberti E., Tassinari C.C.G., Brilli M. 2011. Magmatism and fenitization in the Cretaceous potassium-alkaline-carbonatitic complex of Ipanema São Paulo State, Brazil. Mineralogy and Petrology, 104:43-61. DOI: 10.1007/s00710-011-0168-4

Guedes E., Heilbron M., Vasconcelos P.M., Valeriano C.D., Almeida J.C.H., Teixeira W., Thomaz Filho A. 2005. K-Ar and 40Ar/39Ar ages of dikes emplaced in the onshore basement of the Santos Basin, Resende area, SE Brazil: implications for the south Atlantic opening and Tertiary reactivation. Journal of South American Earth Sciences, 18:371-382. DOI: 10.1016/j.jsames.2004.11.008

Gupta A.K., Dwivedi M.M., Bhattachariya H., Dasgupta S. 2010. Silica-Undersaturated Portion of the System Nepheline-Kalsilite$\mathrm{SiO} 2$ at $2 \mathrm{GPa}[\mathrm{P}(\mathrm{H} 2 \mathrm{O})=\mathrm{P}$ (Total)]. The Canadian Mineralogist, 48:1297-1313. DOI: 10.3749/canmin.48.5.1297

Hamilton D.L. \& MacKenzie W.S. 1965. Phase-equilibrium studies in the system NaAlSiO4 (nepheline) -KAlSiO4 (kalsilite)SiO2-H2O. Mineralogical Magazine, 34:214-231. DOI: 10.1180/ minmag.1965.034.268.17

Harris C., Marsh J.S., Milner S.C. 1999. Petrology of the alkaline core of the Messum igneous complex, Namibia: evidence for the progressively decreasing effect of crustal contamination. Journal of Petrology, 40:1377-1397. DOI: 10.1093/petroj/40.9.1377

Heilbron M., Almeida J.C.H., Silva L.G.E., Palermo N., Tupinambá M., Duarte B.P., Valladares C., Ramos R.C., Ribeiro A., Sanson M. 2007. Geologia e Recursos Minerais das folhas Santa Rita do Jacutinga, Barra do Piraí, Volta Redonda e Angra dos Reis, escala 1:100.000. Brasília, Companhia de Pesquisa de Recursos Minerais.

Heilbron M., Eirado L.G., Almeida J. 2016. Mapa Geológico e de Recursos Minerais do Estado do Rio de Janeiro. Escala 1:400.000. Programa Geologia do Brasil (PGB), Mapas Geológicos Estaduais. Belo Horizonte, CPRM - Serviço Geológico do Brasil, Superintendência Regional de Belo Horizonte.

Heilbron M., Pedrosa-Soares A.C., Campos Neto M.C., Silva L.C., Trouw R.A.J., Janasi V.C. 2004. A Província Mantiqueira. In: Mantesso-Neto V., Bartorelli A., Carneiro C.D.R., Neves B.B.B. (eds.), Geologia do Continente Sul-Americano: Evolução da Obra de Fernando Flávio Marques de Almeida. São Paulo, Beca, p. 203-234.
Janasi V. de A., Andrade S., Vasconcellos A.C.B.C., Henrique-Pinto R., Ulbrich H.H.G.J. 2015. Timing and sources of granite magmatism in the Ribeira Belt, SE Brazil: Insights from zircon in situ U-Pb dating and Hf isotope geochemistry in granites from the São Roque Domain. Journal of South American Earth Sciences, 68:224-247. DOI: 10.1016/j.jsames.2015.11.009

Janasi V. de A., de Freitas V.A., Heaman L.H. 2011. The onset of flood basalt volcanism, Northern Paraná Basin, Brazil: A precise U-Pb baddeleyite/zircon age for a Chapecó-type dacite. Earth and Planetary Science Letters, 302:147-153. DOI: 10.1016/j.epsl.2010.12.005

Janasi V. de A., Vlach S.R.F., Campos Neto M. da C., Ulbrich H.H.G.J. 2009. Associated A-type subalkaline and high-K calc-alkaline granites in the Itu Granite Province, southeastern Brazil: Petrological and tectonic significance. The Canadian Mineralogist, 47:1505-1526. DOI: 10.3749/canmin.47.6.1505

Lamego A.R. 1936. O massiço de Itatiaya e regiões circumdantes. Boletim do Serviço Geológico e Mineralógico, DNPM, 88:1-93.

Lasaulx A. 1885. Üeber das Vorkommen von Eläeolith-Syeniten und editeri zu diesen gehöringen Eläeolith-porphyren aus der Serra d'Itatiaia westlich von Rio de Janeiro, Brasilien. Sitzungsberichte Der Niederrheinischen Gesellschaft Für Natur, 231.

Le Maitre R.W. 2002. Igneous Rocks: A Classification and Glossary of Terms: Recommendations of the International Union of Geological Sciences, Subcommission on the Systematics of Igneous Rocks. Cambridge, Cambridge University Press, 256 p. DOI: 10.1017/ CBO9780511535581

Leite C.A.S., Perrotta M.M., Silva L.C., Silva M.A., Heineck C.A., Salvador E.D., Vieira V.S., Lopes R.C., Silva M.G.M., Drumond J.B.V., Malouf R.F., Lacerda-Filho J.V., Valente C.R., Gomes S.D., Sachs L.L.B., Oliveira I.W.B., Ramgrab G.E., Netto C., Junqueira P.A., Paes V.J.C. 2004. Folhas SF.23 - Rio de Janeiro / SG.23 - Iguape. In: Schobbenhaus C., Gonçalves J.H., Santos J.O.S., Abram M.B., Leão Neto R., Matos G.M.M., Vitotti R.M., Ramos M.A.B., Jesus J.D.A. de (eds.), Carta Geológica do Brasil ao Milionésimo, Sistema de Informações Geográficas. Brasília, Programa Geologia do Brasil, CPRM. 1 CD-ROM.

Mariga J., Ripley E.M., Li C., McKeegan K.D., Groove M., Schmidt A. 2006. Oxygen isotopic disequilibrium in plagioclase-corundumhercynite xenoliths from the Voisey's Bay Intrusion, Labrador, Canada. Earth and Planetary Science Letters, 248:263-275. DOI: 10.1016/j.epsl.2006.05.031

Marks M.A.W., Markl G. 2001. Fractionation and assimilation processes in the alkaline augite syenite unit of the Ilimaussaq Intrusion, South Greenland, as deduced from phase equilibria. Journal of Petrology, 42:1947-1969. DOI: https://doi.org/10.1093/petrology/42.10.1947

Marks M.A.W.W., Hettmann K., Schilling J., Frost B.R., Markl G. 2011. The Mineralogical Diversity of Alkaline Igneous Rocks: Critical Factors for the Transition from Miaskitic to Agpaitic Phase Assemblages. Journal of Petrology, 52:439-455. DOI: 10.1093/petrology/egq086

Marsh I.S. 1973. Relationships between transform directions and alkaline igneous rock lineaments in Africa and South America. Earth and Planetary Science Letters, 18:317-323.

MeislingK.E.\&CobP.R.2001.Segmentation of anobliquelyriftedmargin, CamposandSantos basins, southeastern Brazil.AAPGBulletin, 85:19031924. DOI: 10.1306/8626D0A9-173B-11D7-8645000102C1865D

Mello M.D., Riccomini C., Hasui Y., Almeida F.D., Coimbra A.M. 1985. Geologia e evolução do sistema de bacias tafrogênicas continentais do sudeste do Brasil. Revista Brasileira de Geociências, 15:193-201.

Melluso L., Guarino V., Lustrino M., Morra V., De Gennaro R. 2017. The REE- and HFSE-bearing phases in the Itatiaia Alkaline Complex (Brazil), and geochemical evolution of feldspar-rich felsic melts. Mineralogical Magazine, 81:217-250. DOI: 10.1180/ minmag.2016.080.122 
Mendes J.C., Ávila C.A., Pereira R.M., Heilbron M.P.L., Moura C.A.V. 2006. 207Pb / 206 Pb-ages of zircons from syn-collisional I-type porphyritic granites of the central Ribeira belt, SE Brazil. Gondwana Research, 9:326-336. DOI: 10.1016/j.gr.2005.11.004

Mingram B., Trumbull R.B., Littman S., Gerstenberger H. 2000. A petrogenetic study of anorogenic felsic magmatism in the Cretaceous Paresis ring complex, Namibia: evidence for mixing of crust and mantle-derived components. Lithos, 54:1-22. DOI: 10.1016/S0024-4937(00)00033-5

Mogahed M.M. 2016. Petrogenesis of cogenetic silica-oversaturated and -undersaturated syenites of Abu Khruq ring complex, South Eastern Desert, Egypt. Journal of African Earth Sciences, 124:44-62. DOI: 10.1016/j.jafrearsci.2016.09.010

Motoki A. 1986. Geologia e petrologia do maciço alcalino da Ilha de Vitória, SP. Thesis, Universidade de São Paulo, São Paulo, 245 p. DOI: 10.11606/T.44.1986.tde-30062015-101540

Negrão A.P., Ramos R.R.C., Mello C.L., Sanson M. de S.R. 2015. Mapa geológico do cenozoico da região da bacia de Volta Redonda (RJ, segmento central do Rifte Continental do Sudeste do Brasil): identificação de novos grabens e ocorrências descontínuas, e caracterização de estágios tectonossedimentares. Brazilian Journal of Geology, 45:273-291. DOI: 10.1590/23174889201500020007

Nekvasil H., Dondolini A., Horn J., Filiberto J., Long H., Lindsley D.H. 2004. The Origin and Evolution of Silica-saturated Alkalic Suites: an Experimental Study. Journal of Petrology, 45:693-721. DOI: 10.1093/ petrology/egg103

Njonfang E., Tchoneng G.T., Cozzupoli D., Lucci F. 2013. Petrogenesis of the Sabongari alkaline complex, cameroon line (central Africa): Preliminary petrological and geochemical constraints. Journal of African Earth Sciences, 83:25-54. DOI: 10.1016/j.jafrearsci.2013.03.004

O'Halloran D.A. 1985. Ras ed Dom migrating ring complex: A-type granitesandsyenitesfrom theBayudaDesert,Sudan.Journal of African Earth Sciences, 3:61-75. DOI: 10.1016/0899-5362(85)90023-5

Penalva F. 1967. Geologia e Tectónica da Região do Itatiaia (Sudeste do Brasil). Boletim da Faculdade de Filosofia Ciências e Letras, Universidade de São Paulo. Geologia, 302:99. DOI: 10.11606/ issn.2526-3862.bffcluspgeologia.1967.121904

Pinto O. 1950. Aves do Itatiaia. Boletim do Parque Nacional do Itatiaia, 3:1-87.

Rezende É.A., Augusto A., Salgado R., Silva J.R., Bourlès D.L., Braucher R., Leanni L. 2013. Fatores Controladores da Evolução do Relevo no Flanco Nnw do Rift Continental do Sudeste do Brasil: uma Análise Baseada na Mensuração dos Processos Denudacionais de Longo-Termo Factors Controlling Relief Evolution on the Nnw Flank of the Continental Rift. Revista Brasileira de Geomorfologia, 14(2):221-234. DOI: 10.20502/rbg.v14i2.416

Ribeiro Filho E. 1967. Geologia e Petrologia dos Maciços Alcalinos do Itatiaia e Passa-Quatro (Sudeste do Brasil). Boletim da Faculdade de Filosofia Ciências e Letras, Universidade de São Paulo. Geologia, 302:9. DOI: 10.11606/issn.2526-3862.bffcluspgeologia.1967.121901

Ribeiro Filho E. \& Penalva F. 1965. Mapa Geológico do Maciço Alcalino de Itatiaia [material cartográfico]. 1:50.000. São Paulo, IBGE.

Riccomini C. 1989. O Rift Continental do Sudeste do Brasil. Thesis, Instituto de Geociências, Universidade de São Paulo, São Paulo, 256 p. DOI: 10.11606/T.44.1990.tde-18032013-105507

Riccomini C., Rodrigues-Francisco B.H. 1992. Idade potássio-argônio do derrame de ankaramito da Bacia de Itaboraí, Rio de Janeiro, Brasil: implicações tectônicas. In: Congresso Brasileiro de Geologia, 37. São Paulo, SBG - Sociedade Brasileira de Geologia, p. 469-470.

Riccomini C., Sant'Anna L.G., Ferrari A.L. 2004. Evolução geológica do Rift Continental do Sudeste do Brasil. In: Mantesso Neto V., Bartorelli
A., Carneiro C.D.R., Brito-Neves B.B. (eds.), Geologia do Continente Sul-Americano: Evolução da Obra de Fernando Flávio Marques de Almeida. São Paulo, Beca, p. 383-405.

Riccomini C., Veláquez V.F., Gomes C.B. 2005. Tectonic controls of the Mesozoic and Cenozoic alkaline magmatism in central-southern Brazilian Plataform. In: Comin-Chiaramonti P. \& Gomes C.B. (eds.), Mesozoic to Cenozoic alkaline magmatism in the Brazilian Platform. São Paulo, EDUSP-FAPESP, p. 31-56.

Riishuus M.S., Peate D.W., Tegner C., Wilson J.R., Brooks C.K. 2008. Petrogenesis of Cogenetic Silica-Oversaturated and -Undersaturated Syenites by Periodic Recharge in a Crustally Contaminated Magma Chamber: the Kangerlussuaq Intrusion, East Greenland. Journal of Petrology, 49:493-522. DOI: 10.1093/petrology/egm090

Rosa P.A.S. 2012. Geologia e petrologia da suíte alcalina de Bom Repouso, MG. Dissertation, Instituto de Geociências, Universidade de São Paulo, São Paulo, 156 p. DOI: 10.11606/D.44.2012. tde-11112013-133338

Rosa P.A.S. 2017. Geologia e evolução petrogenética do maciço alcalino de Itatiaia, MG-RJ. Thesis, Instituto de Geociências, Universidade de São Paulo, São Paulo, 137 p.

Rosa P.A.S., Ruberti E., Vasconcelos P.M., Thiede D.S. 2014. 40Ar/39Ar Ages of Bom Repouso Alkaline Suite, MG State. In: South American Symposium on Isotope Geology, 9, 2014. Program and Abstracts, 184.

Sadowski G.R. \& Dias Neto C.M. 1981. O lineamento sismotectônico do Cabo Frio. Revista Brasileira de Geociências, 11:209-212.

Salgado A.A.R., Rezende E. de A., Bourlès D., Braucher R., da Silva J.R., Garcia R.A. 2016. Relief evolution of the Continental Rift of Southeast Brazil revealed by in situ-produced 10Be concentrations in river-borne sediments. Journal of South American Earth Sciences, 67:89-99. DOI: 10.1016/j.jsames.2016.02.002

Schobbenhaus F.C., Campos P.A., Derze G.R., Asmus H.E. 1984 Geologia do Brasil. Brasília, DNPM.

Shea M.E. 1992. Isotopic geochemical characteristics of selected nepheline syenites and phonolites from the Poços de Caldas alkaline complex, Minas Gerais, Brazil. Journal of Geochemical Exploration, 45:173-214. DOI: 10.1016/0375-6742(92)90125-R

Silva J.F. 1876. Descripção do Itatiaia ou Itatiaio. Revista do Instituto Histórico e Geográfico Brasileiro, 39:413-418.

Silva J.F. 1882. Panorama do Sul de Minas. Revista do Instituto Histórico e Geográfico Brasileiro, 45:405-435.

Sørensen H. 1974. The Alkaline Rocks. London, John Wiley \& Sons, $622 \mathrm{p}$

Sørensen H. 1997. The Agpaitic Rocks - An Overview. Mineralogical Magazine, 61:485-498. DOI: 10.1180/minmag.1997.061.407.02

Stanton N., Ponte-Neto C., Bijani R., Masini E., Fontes S., Flexor J.M. 2014. A geophysical view of the Southeastern Brazilian margin at Santos Basin: Insights into rifting evolution. Journal of South American Earth Sciences, 55:141-154. DOI: 10.1016/j. jsames.2014.07.003

Thiede D.S. \& Vasconcelos P.M. 2010. Paraná flood basalts: Rapid extrusion hypothesis confirmed by new 40Ar/39Ar results. Geology. 38:747-750. doi: 10.1130/G30919.1

Thomaz Filho A. \& Rodrigues L. 1999. O Alinhamento de Rochas Alcalinas Poços de Caldas-Cabo Frio (RJ) e sua continuidade na cadeia Vitória-Trindade. Revista Brasileira de Geociências, 29:189-194.

Thompson R.N., Gibson S.A., Mitchell J.G., Dickin A.P., Leonardos O.H., Brod J.A., Greenwood J.C. 1998. Migrating Cretaceous-Eocene Magmatism in the Serra do Mar Alkaline Province, SE Brasil: Melts from the Deflected Trindade Mantle Plume? Journal of Petrology, 39:1493-1526. DOI: doi.org/10.1093/petroj/39.8.1493 
Trouw C.C., Medeiros F.F.F. de, Trouw R.A.J. 2007. Evolução tectônica da Zona de Cisalhamento Caxambu, MG. Revista Brasileira de Geociências, 37:767-776

Trouw R.A.J., Peternel R., Ribeiro A., Heilbron M., Vinagre R., Duffles P., Trouw C.C., Fontainha M., Kussama H.H. 2013. A new interpretation for the interference zone between the southern Brasília belt and the central Ribeira belt, SE Brazil. Journal of South American Earth Sciences, 48:43-57. DOI: 10.1016/j.jsames.2013.07.012

Trouw R.A.J., Ribeiro A., Paciullo F.V.P. 2003. Geologia da Folha Pouso Alto 1:100.000. In: Pedrosa Soares C.A., Noce M.A., Trouw R.A.J., Heilbron M. (eds.), Geologia e Recursos Minerais do Sudeste Mineiro, Projeto Sul de Minas e Etapa I (COMIG, UFMG, UFRJ, UERJ). Belo Horizonte, Companhia Mineradora de Minas Gerais.

Tupinambá M., Heilbron M., Valeriano C., Porto Júnior R., de Dios F.B., Machado N., Silva L.G. do E., de Almeida J.C.H. 2012. Juvenile contribution of the Neoproterozoic Rio Negro Magmatic Arc (Ribeira Belt, Brazil): Implications for Western Gondwana amalgamation. Gondwana Research, 21:422-438. https://doi. org/10.1016/j.gr.2011.05.012

Ulbrich M.N.C. 1993. Mineralogy of nepheline syenites from the Poços de Caldas alkaline massif, SE Brazil: chemistry, X-ray data and microtextures of feldspars. Revista Brasileira de Geociências, 23:388-399.

Valeriano C. de M., Tupinambá M., Simonetti A., Heilbron M., de Almeida J.C.H., do Eirado, L.G. 2011. U-Pb LA-MC-ICPMS geochronology of Cambro-Ordovician post-collisional granites of the Ribeira belt, southeast Brazil: Terminal Brasiliano magmatism in central Gondwana supercontinent. Journal of South American Earth Sciences, 32:416-428. DOI: 10.1016/j.jsames.2011.03.003

Vlach S.R.F., Vilalva F.C.J., Ulbrich M.N.C., Ulbrich H.H.G.J., Vasconcelos P.M. 2003. Phlogopite from carbonatitic veins associated with the Poços de Caldas Alkaline Massif, SE Brazil: Mineralogy and Ar/ $\mathrm{Ar}$ dating by the laser step heating method. In: South American Symposium on Isotope Geology. Salvador, SBG - Sociedade Brasileira de Geologia, p. 702-705.

Yang J.-H.H., Sun J.-F.F., Zhang M., Wu F.-Y.Y., Wilde S.A. 2012. Petrogenesis of silica-saturated and silica-undersaturated syenites in the northern North China Craton related to post-collisional and intraplate extension. Chemical Geology, 328:149-167. DOI: 10.1016/j.chemgeo.2011.09.011

Zalán P.V \& Oliveira J.A.B. 2005. Origem e evolução estrutural do Sistema de Riftes Cenozóicos do Sudeste do Brasil. Boletim de Geociências da Petrobras, 13:269-300. 